\title{
Socio-demographic, clinical and service use determinants associated with HIV related stigma among people living with HIV/AIDS: a systematic review and meta-analysis
}

Bahram Armoon ${ }^{1,2^{*}}$, Peter Higgs ${ }^{3}$, Marie-Josée Fleury ${ }^{1,2,4}$, Amir-Hossien Bayat ${ }^{5}$, Ladan Fattah Moghaddam ${ }^{6}$, Azadeh Bayani ${ }^{7}$ and Yadollah Fakhri ${ }^{8}$

\begin{abstract}
Background: Defining HIV-related stigma (HRS) can be problematic due to structural inequalities, cultural differences, discrimination by health care providers and the limitations of tools measuring stigma for people living with HIV (PLWH). This meta-analysis aimed to determine self-reported HRS and its association with sociodemographic and clinical determinants.

Methods: PubMed, Scopus, Web of Science, Psyclnfo, SciELO and Cochrane electronic databases were searched and after reviewing for study duplicates, the full-text of selected articles were assessed for eligibility using Population, Intervention, Comparator, Outcomes criteria. We used fixed and random-effects meta-analysis models to estimate the pooled prevalence, pooled odds ratio (OR) and 95\% confidence intervals.

Results: Thirty-one studies containing 10,475 participants met the eligibility criteria. Among the potential risk factors: age $>30$ years $(O R=0.93,95 \% C l=0.86,1)$, living with a spouse $(O R=0.07,95 \% C l=0.02,0.17)$, $C D 4$ count $<$ $200(\mathrm{OR}=0.5,95 \% \mathrm{Cl}=0.31,0.68)$, medication adherence $(\mathrm{OR}=0.96,95 \% \mathrm{Cl}=0.94,0.99)$, poor access to care $(\mathrm{OR}=$ $0.79,95 \% \mathrm{Cl}=0.65,0.93)$, time since diagnosis, and accessibility to care $(\mathrm{OR}=0.37,95 \% \mathrm{Cl}=0.11,0.86)$ were all significantly associated with self-reported HIV stigma among PWLH.

Conclusion: Stigma is correlated with numerous negative consequences in marginalised populations including PLWH. Considering the negative association that stigma has on HIV prevention and treatment targeted evidencebased stigma reduction interventions are recommended. Interventions that are focused on a particular group, such as healthcare professionals are warranted. Rigorously designed studies with specific and validated outcome measures associated with targeted interventions may help to improve the reduction of HRS for PLWH.
\end{abstract}

Keywords: HIV-related stigma, CD4 count, Medication adherence, Time since diagnosis

\footnotetext{
* Correspondence: Bahramarmun@gmail.com

${ }^{1}$ Research Center, Douglas Mental Health University Institute, 6875 LaSalle Blvd, Montreal, QC H4H 1R3, Canada

${ }^{2}$ Department of Psychiatry, McGill University, 1033, Pine Avenue West, Montreal, QC H3A 1A1, Canada

Full list of author information is available at the end of the article
}

(c) The Author(s). 2021 Open Access This article is licensed under a Creative Commons Attribution 4.0 International License, which permits use, sharing, adaptation, distribution and reproduction in any medium or format, as long as you give appropriate credit to the original author(s) and the source, provide a link to the Creative Commons licence, and indicate if changes were made. The images or other third party material in this article are included in the article's Creative Commons. licence, unless indicated otherwise in a credit line to the material. If material is not included in the article's Creative Commons licence and your intended use is not permitted by statutory regulation or exceeds the permitted use, you will need to obtain permission directly from the copyright holder. To view a copy of this licence, visit http://creativecommons.org/licenses/by/4.0/. The Creative Commons Public Domain Dedication waiver (http://creativecommons.org/publicdomain/zero/1.0/) applies to the data made available in this article, unless otherwise stated in a credit line to the data. 


\section{Background}

Stigma is a social phenomenon known to have a negative impact on the lives of people living with HIV (PLWH) [1]. However, defining HIV-related stigma (HRS) is difficult because of the intersection it has with structural inequalities, cultural differences, discrimination by health care providers and also the limitations with the tools that measure stigma among PLWH [2-5]. While previous research has examined the association between stigma and HIV treatment, including access to HIV care $[6,7]$, stigma is also considered as a key barrier to HIV antiretroviral therapy (ART) adherence [8]. High rates of stigma have been reported for PLWH who have limited access to ART [9]. Despite previous research suggesting access to ART services can protect against HRS [10], sustained adherence remains crucial in HIV-related care [11]. The effectiveness of HIV prevention and care services are affected by HRS with previous studies describing significant barriers to voluntary testing and counseling among PLWH [12-14]. HRS is associated with difficulties accessing care due to discrimination and fear of rejection from health services [15]. The high levels of stigma experienced by PLWH also affect mental health conditions such as depression [15].

Our study differs from recent research $[6,16]$ as it systematically reviews what has been completed so far and applied odds ratios to determine relationships between socio-demographic, clinical and service use determinants and HRS among PLWH. Rrueda et al. [6] investigated the association of variables such as mental health, physical health, quality of life and medication adherence with HRS and Klein et al. [16] considered interventions to prevent HIV-related stigma and discrimination but did not consider the association between any variables with HRS. To the best of our knowledge no study has considered the demographic and clinical variables such as CD4 $<200$ and other service use variables such as poor access to care, and the impact that time since diagnosis has on care.

Importantly, we not focus only on one variable but include any variable in the meta-analysis. One of the challenges is the small number of high quality studies describing the correlation between socio-demographic, clinical and service use determinants, and insufficient evidence for HIV/AIDS prevention and control programs to inform specific tailored intervention strategies. To understand the factors affecting HRS, this study considered the following outcomes: 1) socio-demographic (age $>30$ years, being female, illiterate and primary education, <\$USD100 monthly income, living with a spouse), 2) clinical factors (CD4 count <200), and 3) service use (previous HIV testing, medication adherence, poor access to care, time since diagnosis and accessibility to care) determinants for HRS among PWLH.
This study is a meta-analysis of peer reviewed journal articles published before November 1, 2020 assessing the correlation between socio-demographic, clinical and service use determinants and HRS among PLWH.

\section{Methods}

\section{Search strategy and study selection}

Our study was implemented using the Protocols of Systematic Reviews and Meta-Analyses (PRISMA) guidelines [17-20].

According to the search strategy and additional manual searches from the article references, 10,457 articles from four databases were found. For the article inclusion, two independent researchers ( $\mathrm{AB}$ and $\mathrm{BA}$ ) reviewed the electronic databases of PubMed, Scopus, Web of science, PsycInfo, SciELO and Cochrane electronic database, with the following search keywords: (Social Determinants of Health [MeSH Terms]) or (Socioeconomic Factors [MeSH Terms]) or (Spouses [MeSH Terms]) or (Literacy [MeSH Terms]) or (Medication Adherence $[\mathrm{MeSH}$ Terms]) or (CD4 Lymphocyte Count [MeSH Terms]) or (Health Services Accessibility [MeSH Terms]) or (Time-to-Treatment [MeSH Terms]) or (Time to diagnosis [Title/Abstract]) or (previous testing [Title/Abstract]) and (HIV [MeSH Terms]) and (social stigma [MeSH Terms]) or stigma [Title/Abstract]) or (shame [MeSH Terms]) or (Self Disclosure [MeSH Terms]) or (Self Concept [MeSH Terms]) or (Negative Self-Image [Title/Abstract]) or (blame [Title/Abstract]) or (feel guilty [Title/Abstract]) and (people who lived with HIV [Title/Abstract]) or (living with HIV [Title/ Abstract]).

We show the search strategy in Table 1 . The references were managed by EndNote X7 software (Thomson Reuters). Duplicate articles were excluded. Initially, two researchers reviewed the extracted article titles and abstracts independently, based on population, intervention, comparison, outcome (PICO) criteria. A third (AMB) member of the research team provided the required input, and resolved disagreements about articles included in the study. Secondly, AB and BA assessed the full articles, considering the study inclusion criteria based on PICO, and exclusion criteria including having no access to the full article and manuscripts missing principal data. Only articles written in English were included.

\section{Inclusion criteria based on PICO}

Population: people living with HIV.

Intervention: PLWH who report HRS.

The comparison group: PLWH not reporting HRS.

Outcomes: Positive and protective association of the social-demographic factors, clinical and service use determinant of PLWH on HRS. 
Table 1 search strategy

\begin{tabular}{llll}
\hline Search & Query & Item \\
number & founds
\end{tabular}

PubMed Search

((((((Social Determinants of Health [MeSH Terms]) OR (Socioeconomic Factors [MeSH Terms])) OR (Spouses [MeSH Terms])) OR (Literacy [MeSH Terms])) OR (((((Medication Adherence [MeSH Terms]) OR (CD4 Lymphocyte Count [MeSH Terms])) OR (Health Services Accessibility [MeSH Terms])) OR (Time-to-Treatment [MeSH Terms])) OR (Time to diagnosis [Title/Abstract])) OR (previous testing [Title/Abstract]))) AND (HIV [MeSH Terms])) AND ((((((social stigma [MeSH Terms]) OR stigma [Title/ Abstract]) OR (shame [MeSH Terms])) OR (Self Disclosure [MeSH Terms])) OR (Self Concept [MeSH Terms])) OR (Negative SelfImage [Title/Abstract])) OR (blame [Title/Abstract])) OR (feel guilty [Title/Abstract]))) AND ((people who lived with HIV [Title/ Abstract]) OR (living with hiv [Title/Abstract]))

HIV [MeSH Terms]

(people who lived with HIV [itle/Abstract]) OR (living with hiv [Title/Abstract])

((((((stigma [Title/Abstract]) OR (shame [MeSH Terms])) OR (Self Disclosure [MeSH Terms])) OR (Self Concept [MeSH Terms])) OR (Negative Self-Image [Title/Abstract])) OR (blame [Title/Abstract])) OR (feel guilty [Title/Abstract])

(((((Medication Adherence [MeSH Terms]) OR (CD4 Lymphocyte Count [MeSH Terms])) OR (Health Services Accessibility [MeSH Terms]]) OR (Time-to-Treatment [MeSH Terms])) OR (Time to diagnosis [Title/Abstract])) OR (previous testing [Title/ Abstract])

21 (((Social Determinants of Health [MeSH Terms]) OR (Socioeconomic Factors [MeSH Terms])) OR (Spouses [MeSH Terms])) OR (Literacy [MeSH Terms])

living with hiv [Title/Abstract]

people who lived with HIV [Title/Abstract]

feel guilty [Title/Abstract]

blame [Title/Abstract]

Negative Self-Image [Title/Abstract]

Self Concept [MeSH Terms]

Self Disclosure [MeSH Terms]

shame [MeSH Terms]

stigma [Title/Abstract]

Social Stigma [MeSH Terms]

previous testing [Title/Abstract]

Time to diagnosis [Title/Abstract]

Time-to-Treatment [MeSH Terms]

Health Services Accessibility [MeSH Terms]

CD4 Lymphocyte Count [MeSH Terms]

Medication Adherence [MeSH Terms]

Literacy [MeSH Terms]

Spouses [MeSH Terms]

Socioeconomic Factors [MeSH Terms]

Social Determinants of Health [MeSH Terms]

Cochrane search

ID Search

\#1 MeSH descriptor: [HIV] explode all trees

\#2 MeSH descriptor: [Social Stigma] explode all trees

\#3 (stigma):ti (Word variations have been searched)

\#4 (people who lived with HIV):ti (Word variations have been searched)

\#5 (Living with HIV):ti (Word variations have been searched)

\#6 MeSH descriptor: [Shame] explode all trees

\#7 MeSH descriptor: [Self Disclosure] explode all trees

\#8 MeSH descriptor: [Self Concept] explode all trees 
Table 1 search strategy (Continued)

\begin{tabular}{ll}
\hline$\# 9$ & (Negative Self-Image):ti (Word variations have been searched) \\
$\# 10$ & (blame):ti (Word variations have been searched) \\
$\# 11$ & (feel guilty):ti (Word variations have been searched) \\
$\# 12$ & MeSH descriptor: [Social Determinants of Health] explode all trees \\
$\# 13$ & MeSH descriptor: [Socioeconomic Factors] explode all trees \\
$\# 14$ & MeSH descriptor: [Spouses] explode all trees \\
$\# 15$ & MeSH descriptor: [Literacy] explode all trees \\
$\# 16$ & MeSH descriptor: [Medication Adherence] explode all trees \\
$\# 17$ & MeSH descriptor: [CD4 Lymphocyte Count] explode all trees \\
$\# 18$ & MeSH descriptor: [Health Services Accessibility] explode all trees \\
$\# 19$ & MeSH descriptor: [Time-to-Treatment] explode all trees \\
$\# 20$ & (Time to diagnosis):ti (Word variations have been searched) \\
$\# 21$ & (previous testing):ti (Word variations have been searched) \\
$\# 22$ & $\# 12$ OR \#13 OR \#14 OR \#15 OR \#16 OR \#17 OR \#18 OR \#19 OR \#20 \\
$\# 23$ & \#2 OR \#3 OR \#6 OR \#7 OR \#8 OR \#9 OR \#10 OR \#11 \\
$\# 24$ & \#4 OR \#5 \\
$\# 25$ & \#22 AND \#1 AND \#23 AND \#24 \\
$\# 26$ & \#22 AND \#23 AND \#24
\end{tabular}

Web of knowledge

\#24 \#21 AND \#22 AND \#23

Indexes = SCI-EXPANDED, SSCI, A\&HCI, CPCI-S, CPCI-SSH, BKCI-S, BKCI-SSH, ESCI, CCR-EXPANDED, IC Timespan = All years

\#23 \#19 OR \#20

Indexes = SCI-EXPANDED, SSCI, A\&HCI, CPCI-S, CPCI-SSH, BKCI-S, BKCI-SSH, ESCI, CCR-EXPANDED, IC Timespan = All years

\#22 \#11 OR \#12 OR \#13 OR \#14 OR \#15 OR \#16 OR \#17 OR \#18 Indexes = SCI-EXPANDED, SSCI, A\&HCI, CPCI-S, CPCI-SSH, BKCI-S, BKCI-SSH, ESCI, CCR-EXPANDED, IC Timespan = All years

\#21 \#1 OR \#2 OR \#3 OR \#4 OR \#5 OR \#6 OR \#7 OR \#8 OR \#9 OR \#10 Indexes = SCI-EXPANDED, SSCI, A\&HCI, CPCI-S, CPCI-SSH, BKCI-S, BKCI-SSH, ESCI, CCR-EXPANDED, IC Timespan = All years

\#20 TI $=$ (Living with HIV) Indexes = SCI-EXPANDED, SSCI, A\&HCl, CPCI-S, CPCI-SSH, BKCI-S, BKCI-SSH, ESCI, CCR-EXPANDED, IC Timespan = All years

\#19 TI = (people who lived with HIV) Indexes = SCI-EXPANDED, SSCI, A\&HCI, CPCI-S, CPCI-SSH, BKCI-S, BKCI-SSH, ESCI, CCR-EXPANDED, IC Timespan = All years

\#18 Tl= (Shame) Indexes = SCI-EXPANDED, SSCI, A\&HCI, CPCI-S, CPCI-SSH, BKCI-S, BKCI-SSH, ESCI, CCR-EXPANDED, IC Timespan = All years

$\# 17 \quad T 1=$ (feel guilty) Indexes = SCI-EXPANDED, SSCI, A\&HCI, CPCI-S, CPCI-SSH, BKCI-S, BKCI-SSH, ESCI, CCR-EXPANDED, IC Timespan = All years

\#16 $\quad \mathrm{Tl}=$ (blame) Indexes $=$ SCI-EXPANDED, SSCI, A\&HCI, CPCI-S, CPCI-SSH, BKCI-S, BKCI-SSH, ESCI, CCR-EXPANDED, IC Timespan = All years

\#15 $T I=$ (Negative Self-Image) Indexes = SCI-EXPANDED, SSCI, A\&HCI, CPCI-S, CPCI-SSH, BKCI-S, BKCI-SSH, ESCI, CCR-EXPANDED, IC Timespan = All years

\#14 Tl $=$ (Self Concept) Indexes = SCI-EXPANDED, SSCI, A\&HCI, CPCI-S, CPCI-SSH, BKCI-S, BKCI-SSH, ESCI, CCR-EXPANDED, IC Timespan = All years

\#13 $\mathrm{Tl}=$ (Self Disclosure) Indexes = SCI-EXPANDED, SSCI, A\&HCI, CPCI-S, CPCI-SSH, BKCI-S, BKCI-SSH, ESCI, CCR-EXPANDED, IC Timespan = All years

\#12 $\mathrm{Tl}=($ Stigma) Indexes = SCI-EXPANDED, SSCI, A\&HCI, CPCI-S, CPCI-SSH, BKCI-S, BKCI-SSH, ESCI, CCR-EXPANDED, IC Timespan = All years

\#11 $\quad \mathrm{Tl}=($ Social Stigma) Indexes = SCI-EXPANDED, SSCI, A\&HCI, CPCI-S, CPCI-SSH, BKCI-S, BKCI-SSH, ESCI, CCR-EXPANDED, IC Timespan = All years

\#10 $\quad \mathrm{Tl}=$ (previous testing) Indexes = SCI-EXPANDED, SSCI, A\&HCI, CPCI-S, CPCI-SSH, BKCI-S, BKCI-SSH, ESCI, CCR-EXPANDED, IC Timespan = All years

\#9 $\quad T I=$ (Time to diagnosis) Indexes = SCI-EXPANDED, SSCI, A\&HCI, CPCI-S, CPCI-SSH, BKCI-S, BKCI-SSH, ESCI, CCR-EXPANDED, IC Timespan = All years 
Table 1 search strategy (Continued)

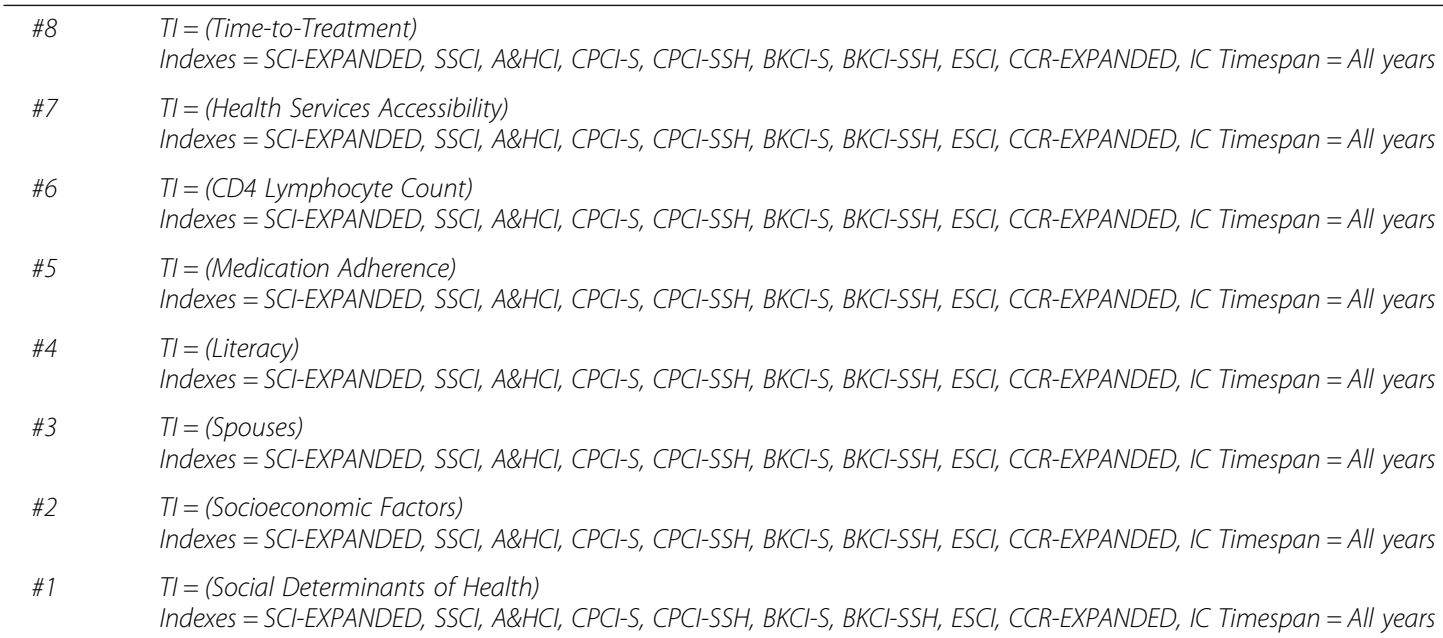

PsycINFO search

("Social Determinants of Health" OR "Socioeconomic Factors OR Spouses OR" Literacy" OR" Medication Adherence" OR "CD4 Lymphocyte Count" OR "Health Services Accessibility OR Time-to-Treatment OR" Time to diagnosis" OR" previous testing") AND ("Shame" OR "Self-Disclosure" OR "Self-Concept" OR "Negative Self-Image" OR "blame" OR "feel guilty") AND ("people who lived with HIV" OR "Living with HIV")

Scielo search

Social Determinants of Health [Title words] or Socioeconomic Factors [Title words] or Spouses [Title words] or Literacy [Title words] or Medication Adherence [Title words] or CD4 Lymphocyte Count [Title words] or Health Services Accessibility [Title words] or Time-to-Treatment [Title words] or Time to diagnosis [Title words] or previous testing [Title words] and Shame [Title words] or Self-Disclosure [Title words] or Self-Concept [Title words] or Negative Self-Image [Title words] or blame [Title words] or feel guilty [Title words] and people who lived with HIV [Title words] or Living with HIV [Title words]

Scopus search

(((TITLE-ABS-KEY (social AND determinants AND of AND health)) OR (TITLE-ABS-KEY (socioeconomic AND factors)) OR (TITLEABS-KEY (spouses)) OR (TITLE-ABS-KEY (literacy))) OR ((TITLE-ABS-KEY (medication AND adherence)) OR (TITLE-ABS-KEY (cd4 AND lymphocyte AND count)) OR (TITLE-ABS-KEY (health AND services AND accessibility)) OR (TITLE-ABS-KEY (time-totreatment)) OR (TITLE-ABS-KEY (time AND to AND diagnosis)) OR (TITLE-ABS-KEY (previous AND testing)))) AND (TITLE-ABSKEY (hiv)) AND ((TITLE-ABS-KEY (stigma)) OR (TITLE-ABS-KEY (social AND stigma)) OR (TITLE-ABS-KEY (shame)) OR (TITLE-ABSKEY (self AND disclosure)) OR (TITLE-ABS-KEY (self AND concept)) OR (TITLE-ABS-KEY (negative AND self-image)) OR (TITLEABS-KEY (blame)) OR (TITLE-ABS-KEY (feel AND guilty))) AND ((TITLE-ABS-KEY (people AND who AND lived AND with AND hiv)) OR (TITLE-ABS-KEY (living AND with AND hiv))) ...View More

((TITLE-ABS-KEY (social AND determinants AND of AND health)) OR (TITLE-ABS-KEY (socioeconomic AND factors)) OR (TITLEABS-KEY (spouses)) OR (TITLE-ABS-KEY (literacy))) OR ((TITLE-ABS-KEY (medication AND adherence)) OR (TITLE-ABS-KEY (cd4 AND lymphocyte AND count)) OR (TITLE-ABS-KEY (health AND services AND accessibility)) OR (TITLE-ABS-KEY (time-totreatment)) OR (TITLE-ABS-KEY (time AND to AND diagnosis)) OR (TITLE-ABS-KEY (previous AND testing))) ...View More (TITLE-ABS-KEY (people AND who AND lived AND with AND hiv)) OR (TITLE-ABS-KEY (living AND with AND hiv))

(TITLE-ABS-KEY (stigma)) OR (TITLE-ABS-KEY (social AND stigma)) OR (TITLE-ABS-KEY (shame)) OR (TITLE-ABS-KEY (self AND disclosure)) OR (TITLE-ABS-KEY (self AND concept)) OR (TITLE-ABS-KEY (negative AND self-image)) OR (TITLE-ABS-KEY (blame)) OR (TITLE-ABS-KEY (feel AND guilty))

5- $\quad$ (TITLE-ABS-KEY (medication AND adherence)) OR (TITLE-ABS-KEY (cd4 AND lymphocyte AND count)) OR (TITLE-ABS-KEY (health AND services AND accessibility)) OR (TITLE-ABS-KEY (time-to-treatment)) OR (TITLE-ABS-KEY (time AND to AND diagnosis)) OR (TITLE-ABS-KEY (previous AND testing))

6- $\quad$ (TITLE-ABS-KEY (social AND determinants AND of AND health)) OR (TITLE-ABS-KEY (socioeconomic AND factors)) OR (TITLEABS-KEY (spouses)) OR (TITLE-ABS-KEY (literacy))

7- $\quad$ TITLE-ABS-KEY (living AND with AND hiv)

8- $\quad$ TITLE-ABS-KEY (people AND who AND lived AND with AND hiv)

9- $\quad$ TITLE-ABS-KEY (feel AND guilty)

10- TITLE-ABS-KEY (blame)

11- $\quad$ TITLE-ABS-KEY (negative AND self-image)

12- $\quad$ TITLE-ABS-KEY (self AND concept) 
Table 1 search strategy (Continued)

\begin{tabular}{ll}
\hline $13-$ & TITLE-ABS-KEY (self AND disclosure) \\
$14-$ & TITLE-ABS-KEY (shame) \\
$15-$ & TITLE-ABS-KEY (social AND stigma) \\
$16-$ & TITLE-ABS-KEY (hiv) \\
$17-$ & TITLE-ABS-KEY (stigma) \\
$18-$ & TITLE-ABS-KEY (hiv) \\
$19-$ & TITLE-ABS-KEY (previous AND testing) \\
$20-$ & TITLE-ABS-KEY (time AND to AND diagnosis) \\
$21-$ & TITLE-ABS-KEY (time-to-treatment) \\
$22-$ & TITLE-ABS-KEY (health AND services AND accessibility) \\
$23-$ & TITLE-ABS-KEY (cd4 AND lymphocyte AND count) \\
$24-$ & TITLE-ABS-KEY (medication AND adherence) \\
$25-$ & TITLE-ABS-KEY (literacy) \\
$26-$ & TITLE-ABS-KEY (spouses) \\
$27-$ & TITLE-ABS-KEY (socioeconomic AND factors) \\
\hline
\end{tabular}

We reviewed cross-sectional, cohort, and case-control studies. According to the PICO criteria, for the "population", only PLWH were included; the "intervention" targeted HRS; the "comparison" group was PLWH not reporting HRS; "outcomes" were the significant association of the social-demographic factors, clinical and service use determinant of HRS on PLWH.; "study design" included cross-sectional, cohort or case-control studies. Qualitative studies, secondary studies not reporting primary data, systematic reviews and meta-analysis studies were excluded. Articles that had major heterogeneity or outcome variations from the study groups were excluded. Articles or variables that were not investigated extensively enough to be included in the meta-analysis were also not considered as associated variables of HRS among PLWH (i.e. opportunistic infection, quality of life, self-efficacy, helplessness previous testing, HIV knowledge, prison history).

\section{Instruments}

Berger Stigma Scale, [21] HIV Stigma Measure, [22] Internalized AIDS-Related Stigma Scale, [23] and DemiHIV Stigma Scale were the most frequently applied tools for measuring HIV-related stigma.

\section{Data extraction and study quality assessment}

The quality of each paper was evaluated applying the Newcastle-Ottawa Scale [24] recommended by the Cochrane Collaboration [25] (See Table 2). Two researchers $(\mathrm{AB}$ and $\mathrm{BA})$ evaluated the studies separately applying a standardized data collection form (excel form). Any contradictions of opinions about quality of overall studies between the authors were resolved by YF and $A B$ through discussion. The surname of the first author, publication year, demographic data of participants (age $>30$ years, living with spouse, education) and other features such as CD4 count $<200$, previous HIV testing and service use determinants such as medication adherence, poor access to care, time since diagnosis and accessibility to care were recorded during the data extraction.

\section{Data synthesis and statistical analysis}

The meta-analysis was produced by pooling odds ratios (ORs) with 95\% confidence intervals recognizing social and risk-taking behaviors related to HIV stigma among PLWH. We applied Q test with a $P$ value $<0.05$ and $\mathrm{I}^{2}$ statistics with a cutoff of $\geq 50 \%$ to evaluate the correlations across the studies. We also obtained uncertainty $95 \%$ confidence intervals for $\mathrm{I}^{2}$. We assumed any negative values to I2 as equal to zero. We used the random effects model to compute pooled estimations, taking into account the different sampling methods of the selected studies. To recognize any publication bias, Begg's and Egger's approach was performed both graphically and statistically $[55,56]$. We considered the $P$ value of 0.05 as statistically significant. The association between socio-demographic, clinical and service use determinants and HRS were proposed by an OR and $95 \% \mathrm{CI}$. We visualized the obtained results in forest plots. For data analysis, R 3.5.1 with the "meta" package was applied to perform the meta-analysis.

\section{Results}

\section{Study characteristics}

The study selection process is shown in Fig. 1. There were 10,457 published papers founded in the 6 databases searched, including the article references reviewed. After 
Table 2 Risk of bias assessment using Newcastle-Ottawa scale

\begin{tabular}{|c|c|c|c|c|c|c|}
\hline Study & $\begin{array}{l}\text { Selection } \\
(* * *)\end{array}$ & $\begin{array}{l}\text { Comparability } \\
(*)\end{array}$ & $\begin{array}{l}\text { Exposure/ } \\
\text { outcome } \\
(*)\end{array}$ & Method of assessment & $\begin{array}{l}\text { Quality } \\
\text { Assessment }\end{array}$ & $\begin{array}{l}\text { Quality } \\
\text { Assessment score }\end{array}$ \\
\hline Charles et al. [9] & $* * *$ & & * & $\begin{array}{l}\text { Newcastle-Ottawa scale adapted for } \\
\text { cross-sectional studies }\end{array}$ & Good & 4 \\
\hline Waite et al. [26] & * & * & * & $\begin{array}{l}\text { Newcastle-Ottawa scale adapted for } \\
\text { cross-sectional studies }\end{array}$ & Satisfactory & 3 \\
\hline Li et al. [27] & $* *$ & * & * & $\begin{array}{l}\text { Newcastle-Ottawa scale adapted for } \\
\text { cross-sectional studies }\end{array}$ & Good & 4 \\
\hline Egbe et al. [28] & $* * *$ & & * & $\begin{array}{l}\text { Newcastle-Ottawa scale adapted for } \\
\text { cross-sectional studies }\end{array}$ & Good & 4 \\
\hline Emlet et al. [29] & $* * *$ & * & & $\begin{array}{l}\text { Newcastle-Ottawa scale adapted for } \\
\text { cross-sectional studies }\end{array}$ & Good & 4 \\
\hline Akena et al. [30] & * & * & * & $\begin{array}{l}\text { Newcastle-Ottawa scale adapted for } \\
\text { cross-sectional studies }\end{array}$ & Satisfactory & 3 \\
\hline $\begin{array}{l}\text { Letshwenyo-Maruatona } \\
\text { et al. [31] }\end{array}$ & $*$ & * & * & $\begin{array}{l}\text { Newcastle-Ottawa scale adapted for } \\
\text { cross-sectional studies }\end{array}$ & Satisfactory & 3 \\
\hline Chan et al. [32] & $* *$ & * & * & $\begin{array}{l}\text { Newcastle-Ottawa scale adapted for } \\
\text { cross-sectional studies }\end{array}$ & Good & 4 \\
\hline Wu et al. [33] & $* * *$ & $*$ & * & $\begin{array}{l}\text { Newcastle-Ottawa scale adapted for } \\
\text { cross-sectional studies }\end{array}$ & Very Good & 5 \\
\hline $\begin{array}{l}\text { Rael and Hampanda } \\
\text { [34] }\end{array}$ & $* *$ & * & * & $\begin{array}{l}\text { Newcastle-Ottawa scale adapted for } \\
\text { cross-sectional studies }\end{array}$ & Good & 4 \\
\hline Zhang et al. [35] & $* *$ & * & * & $\begin{array}{l}\text { Newcastle-Ottawa scale adapted for } \\
\text { cross-sectional studies }\end{array}$ & Good & 4 \\
\hline $\begin{array}{l}\text { Peltzer and Ramlagan } \\
\text { [36] }\end{array}$ & $* * *$ & * & * & $\begin{array}{l}\text { Newcastle-Ottawa scale adapted for } \\
\text { cross-sectional studies }\end{array}$ & Very Good & 5 \\
\hline Zhang et al. [37] & $* *$ & * & * & $\begin{array}{l}\text { Newcastle-Ottawa scale adapted for } \\
\text { cross-sectional studies }\end{array}$ & Good & 4 \\
\hline $\begin{array}{l}\text { Srithanaviboonchai } \\
\text { et al. [38] }\end{array}$ & $* *$ & * & * & $\begin{array}{l}\text { Newcastle-Ottawa scale adapted for } \\
\text { cross-sectional studies }\end{array}$ & Good & 4 \\
\hline Li et al. [39] & $* *$ & * & * & $\begin{array}{l}\text { Newcastle-Ottawa scale adapted for } \\
\text { cross-sectional studies }\end{array}$ & Good & 4 \\
\hline Stangl et al. [40] & $* * *$ & * & * & $\begin{array}{l}\text { Newcastle-Ottawa scale adapted for } \\
\text { cross-sectional studies }\end{array}$ & Very Good & 5 \\
\hline Stevelink et al. [41] & $* * *$ & * & * & $\begin{array}{l}\text { Newcastle-Ottawa scale adapted for } \\
\text { cross-sectional studies }\end{array}$ & Very Good & 5 \\
\hline Zhang et al. [42] & $* * *$ & * & * & $\begin{array}{l}\text { Newcastle-Ottawa scale adapted for } \\
\text { cross-sectional studies }\end{array}$ & Very Good & 5 \\
\hline Rivera et al. [43] & $* *$ & * & * & $\begin{array}{l}\text { Newcastle-Ottawa scale adapted for } \\
\text { cross-sectional studies }\end{array}$ & Good & 4 \\
\hline Sayles et al. [15] & $*$ & * & * & $\begin{array}{l}\text { Newcastle-Ottawa scale adapted for } \\
\text { cross-sectional studies }\end{array}$ & Satisfactory & 3 \\
\hline Li et al. [44] & $* *$ & * & * & $\begin{array}{l}\text { Newcastle-Ottawa scale adapted for } \\
\text { cross-sectional studies }\end{array}$ & Good & 4 \\
\hline Genberg et al. [45] & $* *$ & * & * & $\begin{array}{l}\text { Newcastle-Ottawa scale adapted for } \\
\text { cross-sectional studies }\end{array}$ & Good & 4 \\
\hline Earnshaw et al. [46] & $* * *$ & * & * & $\begin{array}{l}\text { Newcastle-Ottawa scale adapted for } \\
\text { cross-sectional studies }\end{array}$ & Very Good & 5 \\
\hline Burke et al. [47] & $* * *$ & * & * & $\begin{array}{l}\text { Newcastle-Ottawa scale adapted for } \\
\text { cross-sectional studies }\end{array}$ & Very Good & 5 \\
\hline Turan et al. [48] & $* *$ & * & * & $\begin{array}{l}\text { Newcastle-Ottawa scale adapted for } \\
\text { cross-sectional studies }\end{array}$ & Good & 4 \\
\hline Mao et al. [49] & $* *$ & * & * & $\begin{array}{l}\text { Newcastle-Ottawa scale adapted for } \\
\text { cross-sectional studies }\end{array}$ & Good & 4 \\
\hline
\end{tabular}


Table 2 Risk of bias assessment using Newcastle-Ottawa scale (Continued)

\begin{tabular}{|c|c|c|c|c|c|c|}
\hline Study & $\begin{array}{l}\text { Selection } \\
(* * *)\end{array}$ & $\begin{array}{l}\text { Comparability } \\
(*)\end{array}$ & $\begin{array}{l}\text { Exposure/ } \\
\text { outcome } \\
\left({ }^{*}\right)\end{array}$ & Method of assessment & $\begin{array}{l}\text { Quality } \\
\text { Assessment }\end{array}$ & $\begin{array}{l}\text { Quality } \\
\text { Assessment score }\end{array}$ \\
\hline Zhang et al. [50] & $*$ & * & * & $\begin{array}{l}\text { Newcastle-Ottawa scale adapted for } \\
\text { cross-sectional studies }\end{array}$ & Satisfactory & 3 \\
\hline Rintamaki et al. [51] & $* *$ & * & * & $\begin{array}{l}\text { Newcastle-Ottawa scale adapted for } \\
\text { cross-sectional studies }\end{array}$ & Good & 4 \\
\hline Liu et al. [52] & $* *$ & * & * & $\begin{array}{l}\text { Newcastle-Ottawa scale adapted for } \\
\text { cross-sectional studies }\end{array}$ & Good & 4 \\
\hline Wolitski et al. [53] & $* *$ & * & * & $\begin{array}{l}\text { Newcastle-Ottawa scale adapted for } \\
\text { cross-sectional studies }\end{array}$ & Good & 4 \\
\hline $\begin{array}{l}\text { Levi-Minzi and Surratt } \\
\text { [54] }\end{array}$ & $* * *$ & * & * & $\begin{array}{l}\text { Newcastle-Ottawa scale adapted for } \\
\text { cross-sectional studies }\end{array}$ & Very Good & 5 \\
\hline
\end{tabular}

Cross-sectional studies:

* Unsatisfactory studies

*** Satisfactory studies

**** Good studies

***** Very good studies

article duplicates were excluded, assessments of abstracts completed and full text papers evaluated, 31 studies were retained for inclusion in this meta-analysis $[9,15,26-$ 54].

Out of the 31 studies, 10 were based on data collected from the Americas [ $n=5108$ participants], seven from the African Region [ $n=24,182$ participants], one from the European Region [ $n=381$ participants], three from South-East Asia [ $n=11,112$ participants] and ten from the Western Pacific Region [ $n=17,845$ participants]. China was the country with the highest number of included studies (10 studies, 11,112 participants). Considering the World Bank country income level, 9 studies ( $n=4877)$ were from high-income countries, 16 studies $(n=37,812)$ from an upper middle income country, 4 studies $(n=15,342)$ were from lower middle income countries and 2 studies $(n=597)$ were from lower income countries.

\section{Results of the meta-analysis}

We analyzed the association of socio-demographic (age > 30 years, being female, illiterate and primary education, $<$ USD100 monthly income, living with a spouse), clinical (CD4 count <200,), and service use (previous HIV testing, medication adherence, poor access to care, time since diagnosis and accessibility to care) determinants for HRS among PWLH (see Table 3). These relationships were derived from information obtained from studies that recruited about 70,000 PLWH.

Plots 2 to 11 represent the associations we found. As illustrated in Figs. 2, 3, 4, 5, there were no significant associations between being female, $(\mathrm{OR}=1.43,95 \% \mathrm{CI}=$ 0.76-2.09), illiterate and primary education $(\mathrm{OR}=0.99$, $95 \% \mathrm{CI}=0.83-1.14), \quad<$ SUD100 monthly income (OR = $1.01,95 \% \mathrm{CI}=0.85-1.17)$, and previous HIV testing and HRS $(\mathrm{OR}=0.96,95 \% \mathrm{CI}=0.87-1.04)$.

\section{Socio-demographic determinants}

The association of age $>30$ years on HRS among PLWH

The protective association of age $>30$ years on HRS among PLWH is shown in Fig. 6 and the source of heterogeneity that has been achieved is $92.8 \%$. The pooled effect size has a protective association and its lower bound is about 0.86 and the higher bound about 1 . The OR 0.93 indicates a protective association for age $>30$ years on reporting $\mathrm{HRS}(\mathrm{OR}=0.93,95 \% \mathrm{CI}=0.86,1)$.

\section{The association of living with a spouse on HRS among PLWH}

Our finding indicates a protective association between residing with a spouse and reporting HRS. PLWH living with a spouse were less likely to have reported HRS $(\mathrm{OR}=0.07,95 \% \mathrm{CI}=0.02,0.17)$ and the heterogeneity is about $0 \%$ indicating variability in the data (See Fig. 7).

\section{Clinical determinants}

\section{The association of CD4 count $<200$ on HRS among PLWH}

Four of the studies [30, 36, 46, 51] examined the association of CD4 count $<200$ on HRS. Two studies from high-income countries $[46,51]$, one from a upper middle-income country [36] and one study was conducted in a low income country setting [30]. The studies were published between 2011 and 2019, and the sample sizes ranged from 95 to 735 . All four studies used a cross-sectional design. The results of CD4 count on HRS among PLWH are presented in Fig. 8. There is a protective association between CD4 count $(C D 4<200)$ and the reporting of HRS. Those PLWH with CD $4<200$ were 0.5 times less likely to have $\mathrm{HRS}(\mathrm{OR}=0.5,95 \% \mathrm{CI}=0.31,0.68)$ and the heterogeneity is $0 \%$ (See Fig. 8). 
Table 3 Main characteristics of the studies selected

\begin{tabular}{|c|c|c|c|c|c|c|c|}
\hline Author & Participants & $\begin{array}{l}\text { Year of } \\
\text { publish }\end{array}$ & $\begin{array}{l}\text { Sample } \\
\text { size }\end{array}$ & $\begin{array}{l}\text { Year of } \\
\text { implementation }\end{array}$ & Country & Design & $\begin{array}{l}\text { Quality of the } \\
\text { evidence }\end{array}$ \\
\hline Charles et al. [9] & PLWHA & 2012 & 400 & 2009 & India & $\begin{array}{l}\text { Cross- } \\
\text { section }\end{array}$ & Good \\
\hline Waite et al. [26] & PLWHA & 2008 & 204 & 2001 & USA & $\begin{array}{l}\text { Cross- } \\
\text { section }\end{array}$ & Satisfactory \\
\hline Li et al. [27] & PLWHA & 2018 & 239 & 2014 & China & $\begin{array}{l}\text { Cross- } \\
\text { section }\end{array}$ & Good \\
\hline Egbe et al. [28] & PLWHA & 2020 & 385 & 2018 & Cameron & $\begin{array}{l}\text { Cross- } \\
\text { section }\end{array}$ & Good \\
\hline Emlet et al. [29] & PLWHA & 2014 & 960 & 2013 & Canada & $\begin{array}{l}\text { Cross- } \\
\text { section }\end{array}$ & Good \\
\hline Akena et al. [30] & PLWHA & 2012 & 368 & 2012 & Uganda & $\begin{array}{l}\text { Cross- } \\
\text { section }\end{array}$ & Satisfactory \\
\hline $\begin{array}{l}\text { Letshwenyo-Maruatona } \\
\text { et al. [31] }\end{array}$ & PLWHA & 2019 & 4045 & 2013 & Botswana & $\begin{array}{l}\text { Cross- } \\
\text { section }\end{array}$ & Satisfactory \\
\hline Chan et al. [32] & PLWHA & 2012 & 229 & 2006-2011 & Uganda & $\begin{array}{l}\text { Cross- } \\
\text { section }\end{array}$ & Good \\
\hline Wu et al. [33] & PLWHA & 2015 & 940 & $2010-211$ & China & $\begin{array}{l}\text { Cross- } \\
\text { section }\end{array}$ & Very Good \\
\hline Rael and Hampanda [34] & PLWHA & 2015 & 231 & 2014 & Mexico & $\begin{array}{l}\text { Cross- } \\
\text { section }\end{array}$ & Good \\
\hline Zhang et al. [35] & PLWHA & 2019 & 193 & 2018 & China & $\begin{array}{l}\text { Cross- } \\
\text { section }\end{array}$ & Good \\
\hline Peltzer and Ramlagan [36] & PLWHA & 2011 & 735 & $2007-2008$ & South African & $\begin{array}{l}\text { Cross- } \\
\text { section }\end{array}$ & Very Good \\
\hline Zhang et al. [37] & PLWHA & 2016 & 2987 & 2012-2013 & China & $\begin{array}{l}\text { Cross- } \\
\text { section }\end{array}$ & Good \\
\hline $\begin{array}{l}\text { Srithanaviboonchai et al. } \\
\text { [38] }\end{array}$ & PLWHA & 2017 & 10,522 & 2014 & Thailand & $\begin{array}{l}\text { Cross- } \\
\text { section }\end{array}$ & Good \\
\hline Li et al. [39] & PLWHA & 2017 & 4050 & $2007-2008$ & China & $\begin{array}{l}\text { Cross- } \\
\text { section }\end{array}$ & Good \\
\hline Stangl et al. [40] & PLWHA & 2019 & 4053 & 2013-2015 & $\begin{array}{l}\text { South Africa and } \\
\text { Zambia }\end{array}$ & $\begin{array}{l}\text { Cross- } \\
\text { section }\end{array}$ & Very Good \\
\hline Stevelink et al. [41] & PLWHA & 2011 & 190 & 2009 & India & $\begin{array}{l}\text { Cross- } \\
\text { section }\end{array}$ & Very Good \\
\hline Zhang et al. [42] & PLWHA & 2016 & 2987 & 2012-2013 & China & $\begin{array}{l}\text { Cross- } \\
\text { section }\end{array}$ & Very Good \\
\hline Rivera et al. [43] & PLWHA & 2015 & 716 & 2015 & USA & $\begin{array}{l}\text { Cross- } \\
\text { section }\end{array}$ & Good \\
\hline Sayles et al. [15] & PLWHA & 2009 & 202 & 2007 & USA & $\begin{array}{l}\text { Cross- } \\
\text { section }\end{array}$ & Satisfactory \\
\hline Li et al. [44] & PLWHA & 2011 & 202 & 2009 & China & $\begin{array}{l}\text { Cross- } \\
\text { section }\end{array}$ & Good \\
\hline Genberg et al. [45] & PLWHA & 2009 & 14,367 & 2005-2006 & Sub-Saharan Africa & $\begin{array}{l}\text { Cross- } \\
\text { section }\end{array}$ & Good \\
\hline Earnshaw et al. [46] & PLWHA & 2013 & 95 & 2013 & USA & $\begin{array}{l}\text { Cross- } \\
\text { section }\end{array}$ & Very Good \\
\hline Burke et al. [47] & PLWHA & 2020 & 381 & 2012-2014 & Russia & $\begin{array}{l}\text { Cross- } \\
\text { section }\end{array}$ & Very Good \\
\hline Turan et al. [48] & PLWHA & 2017 & 1356 & 2014-2015 & USA & $\begin{array}{l}\text { Cross- } \\
\text { section }\end{array}$ & Good \\
\hline Mao et al. [49] & PLWHA & 2017 & 1254 & 2012-2013 & China & $\begin{array}{l}\text { Cross- } \\
\text { section }\end{array}$ & Good \\
\hline Zhang et al. [50] & PLWHA & 2016 & 2987 & $2012-2013$ & China & Cross- & Satisfactory \\
\hline
\end{tabular}


Table 3 Main characteristics of the studies selected (Continued)

\begin{tabular}{|c|c|c|c|c|c|c|c|}
\hline Author & Participants & $\begin{array}{l}\text { Year of } \\
\text { publish }\end{array}$ & $\begin{array}{l}\text { Sample } \\
\text { size }\end{array}$ & $\begin{array}{l}\text { Year of } \\
\text { implementation }\end{array}$ & Country & Design & $\begin{array}{l}\text { Quality of the } \\
\text { evidence }\end{array}$ \\
\hline & & & & & & section & \\
\hline Rintamaki et al. [51] & PLWHA & 2019 & 204 & 2001 & USA & $\begin{array}{l}\text { Cross- } \\
\text { section }\end{array}$ & Good \\
\hline Liu et al. [52] & PLWHA & 2020 & 2006 & 2016 & China & $\begin{array}{l}\text { Cross- } \\
\text { section }\end{array}$ & Good \\
\hline Wolitski et al. [53] & PLWHA & 2008 & 637 & 2008 & USA & $\begin{array}{l}\text { Cross- } \\
\text { section }\end{array}$ & Good \\
\hline Levi-Minzi and Surratt [54] & PLWHA & 2014 & 503 & 2014 & USA & $\begin{array}{l}\text { Cross- } \\
\text { section }\end{array}$ & Very Good \\
\hline
\end{tabular}

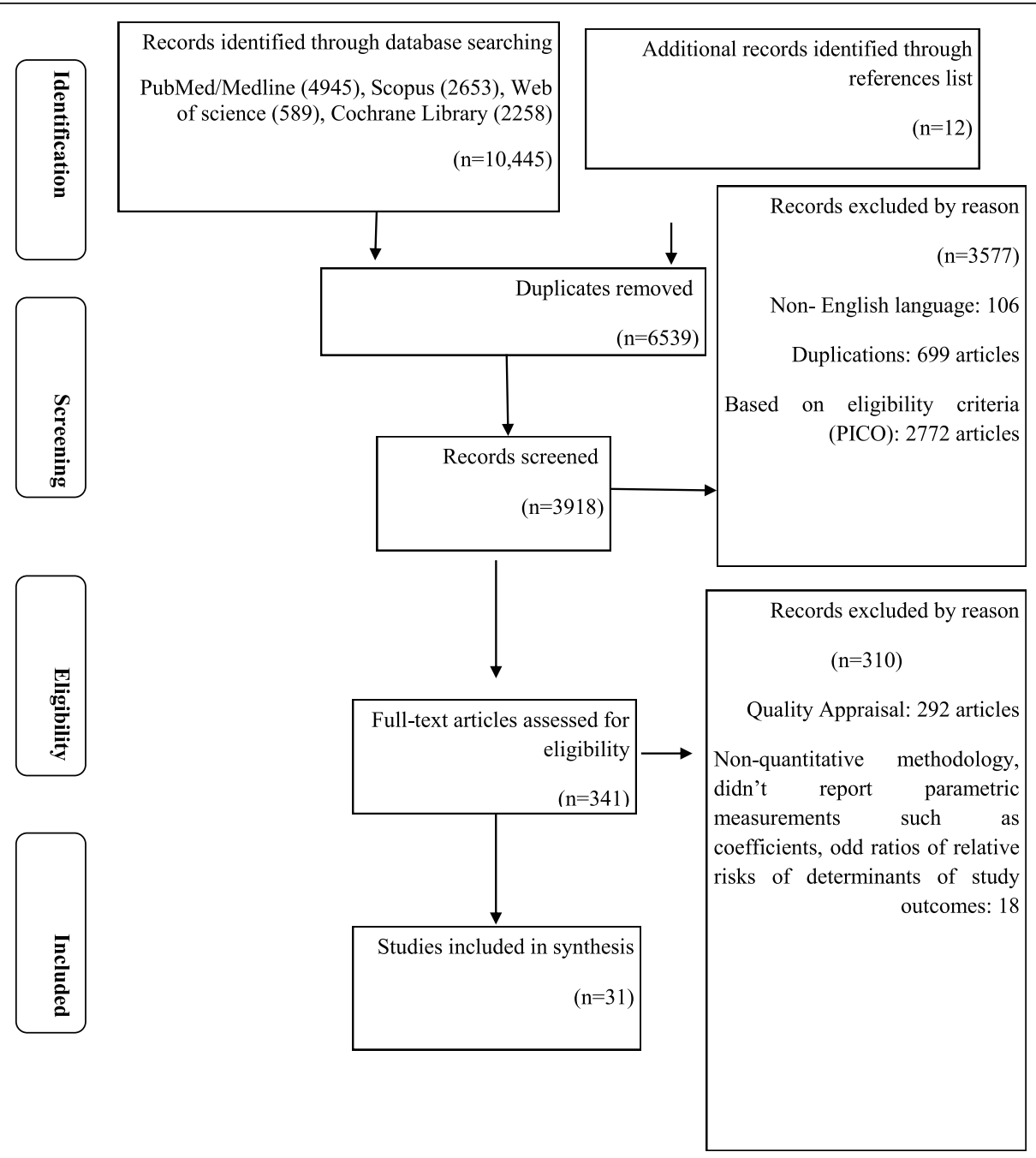

Fig. 1 PRISMA flow diagram 


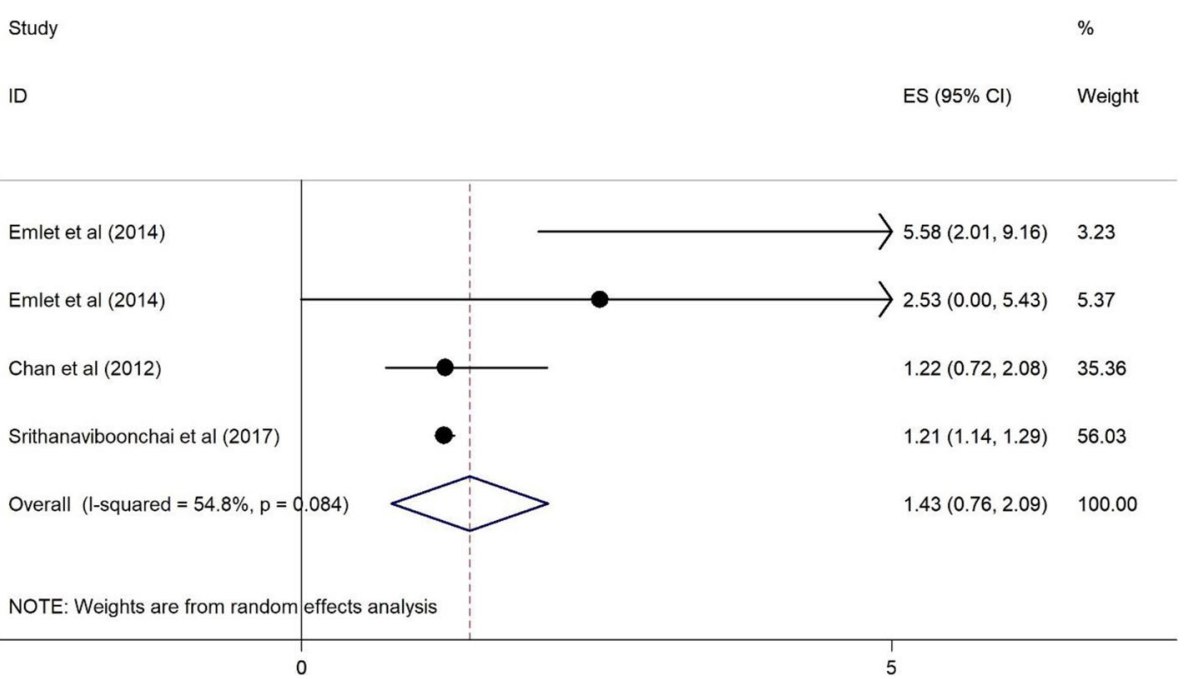

Fig. 2 Forest plots for the association between being female and HIV related stigma among PLWH

\section{Service use determinants}

\section{The association of medication adherence on HRS among} PLWH

Six cross-sectional studies [44, 47, 48, 50, 53, 54] examined the relationship between ART adherence and HRS. Three studies were conducted in high-income countries [48, 50, 53, 54] and published between 2008 and 2020 with sample sizes ranging from 202 to 2987.

As illustrated in Fig. 9 medication adherence has a protective association on the reporting of HRS among participants. The heterogeneity statistic is about $7.7 \%$, and the pooled effect size implies a relative neutral association. Those respondents who reported medication adherence were 0.96 times less likely to report HRS $(\mathrm{OR}=0.96,95 \% \mathrm{CI}=0.94,0.99)$ (See Fig. 9).

\section{The association of poor access to care on HRS among PLWH}

Five studies [9, 15, 26, 45, 48] examined the association of poor access to care on HRS, three from high-income countries [15, 26, 48]. One study was based in a lower middle-income country [9] and the last study was conducted in a low income country [45]. The studies were published between 2008 to 2017, and the sample sizes

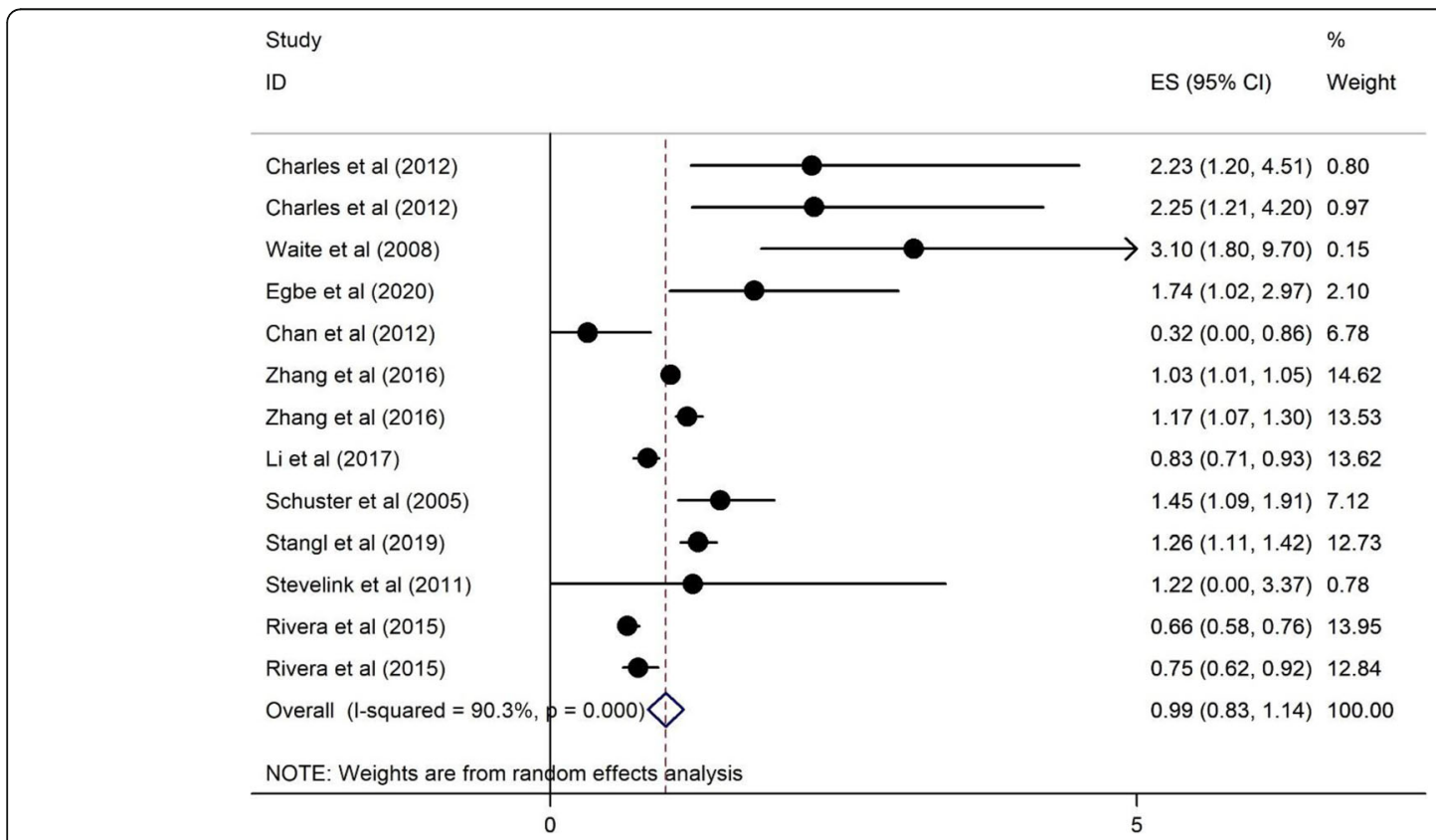

Fig. 3 Forest plots for the association between non-literate and primary education and HIV related stigma among PLWH 


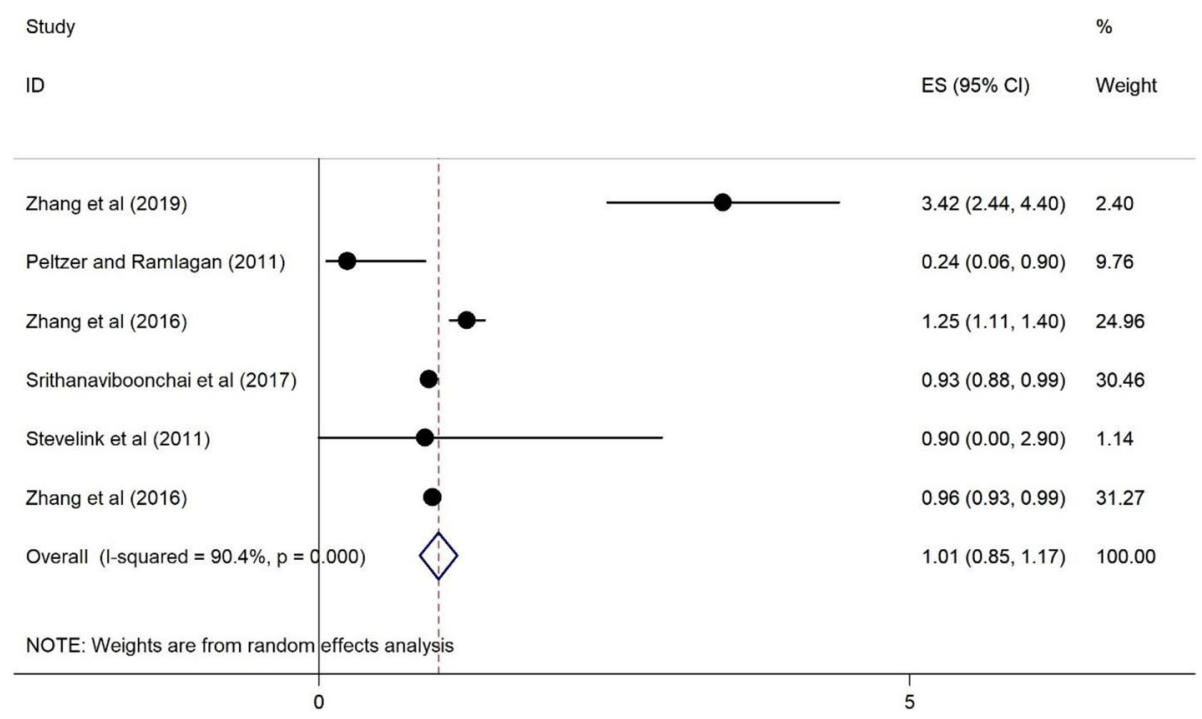

Fig. 4 Forest plots for the association between income $(<100 \$)$ and HIV related stigma among PLWH

ranged from 202 to 14,367. All four studies used a cross -sectional design. The access to care results are presented in Fig. 10. They show a protective association between poor access to care and HRS among PLWH. Those respondents who reported poor access to care were less likely to report HRS (OR $=0.79,95 \% \mathrm{CI}=0.65$, 0.93 ) and the heterogeneity is $51.3 \%$ (See Fig. 10).

The association of time since diagnosis and accessibility to care on HRS among PLWH

Our results include three cross sectional studies that assessed the association of time since HIV diagnosis and accessibility to care on HRS. One study from an upper middle income country [49], one was from low income country [32] and one study from a high income country [29]. Studies were published between 2015 to 2017, and the sample sizes ranged from 220 to 1254 .

Figure 11 shows the protective association between time since HIV diagnosis and accessibility to hospital services and the association that has on HRS among PLWH. Those who diagnosed early were less likely to report experiencing $\mathrm{HRS}(\mathrm{OR}=0.37,95 \% \mathrm{CI}=0.11,0.86)$.

\section{Publication bias}

The publication bias was significant in the demographical subgroup including those with incomes of $>\$ 100$

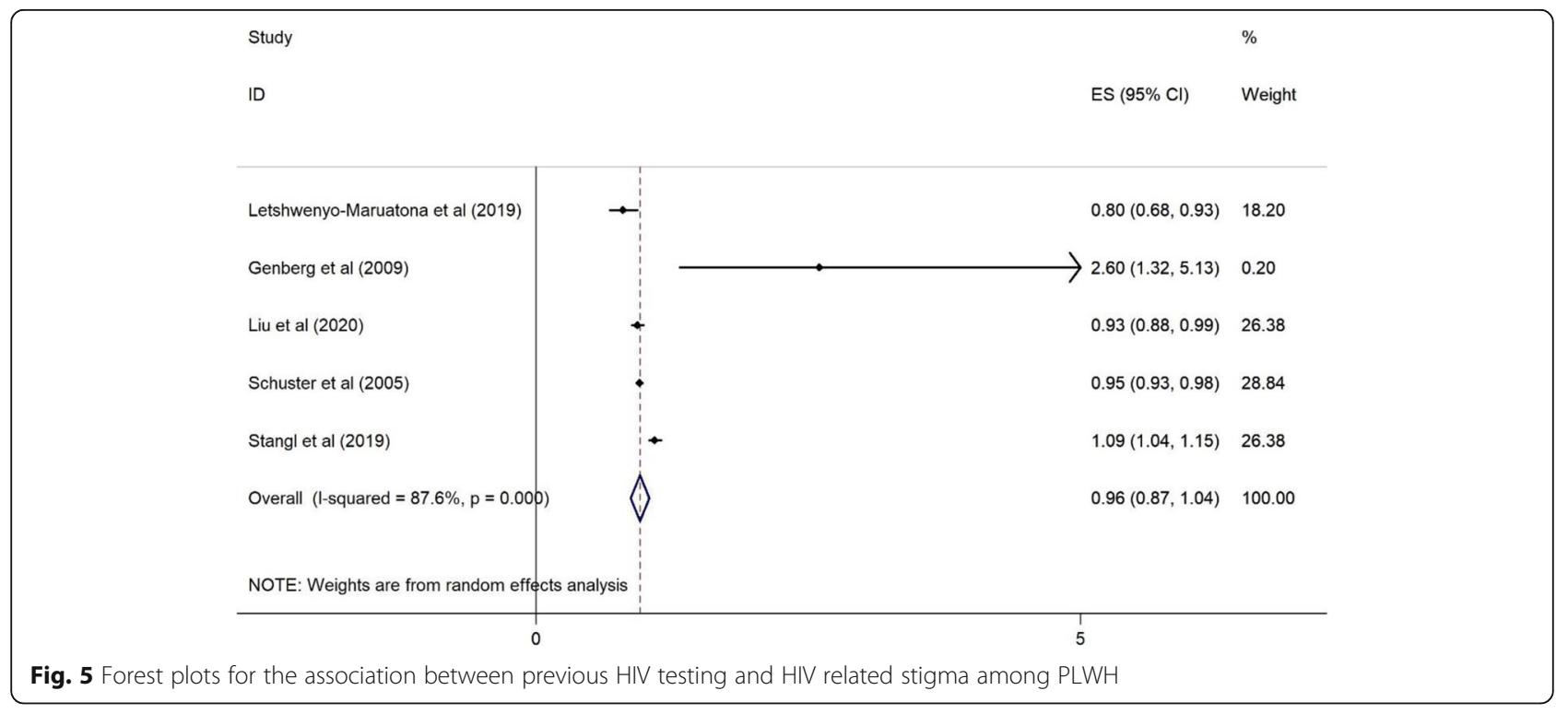




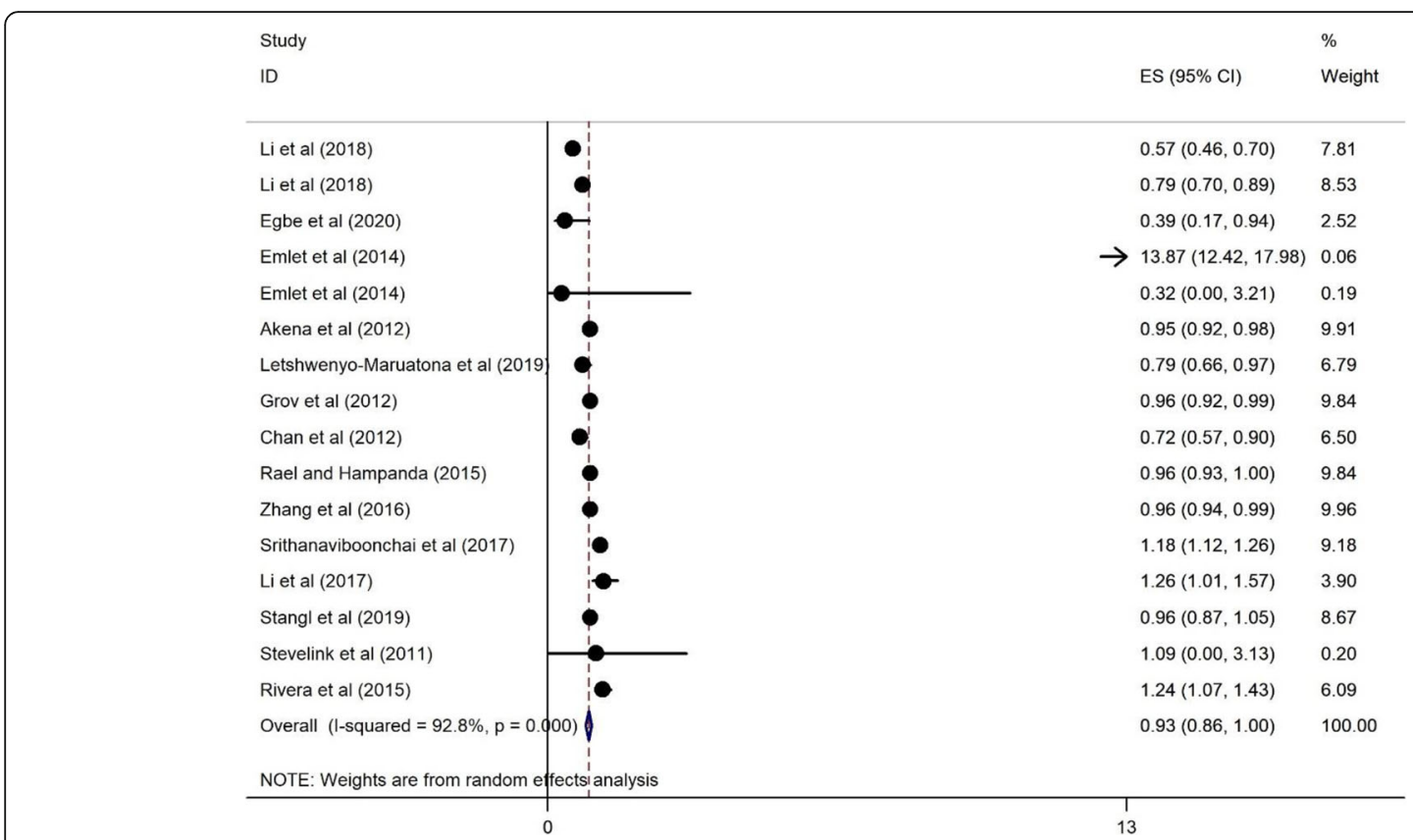

Fig. 6 Forest plots for the association between age $>30$ years and HIV related stigma among PLWH

USD per month $(\mathrm{C}=10.09, \quad P \quad$ value $=0.015) \quad($ See Table 4).

\section{Discussion}

This review explored the correlations between various socio-demographic, clinical, and service use and HRS. We examined and integrated the outcomes from 31 peer-reviewed publications published before November 2020. Significant variability was detected in terms of evaluating the socio-demographic of study participants and the reporting of HIV-related stigma. We found significant and consistent associations between reporting stigma and being aged over 30 years, living with a spouse, as socio-demographic factors and having CD4 counts of $<200$, HIV medication adherence, overall poor access to care, length of time since diagnosis and accessibility to HIV care as service use.

Assumption 1: socio-demographic characteristics have an association on HRS among PLWH

We found that living with a spouse was an important factor in reporting health related stigma. This finding is

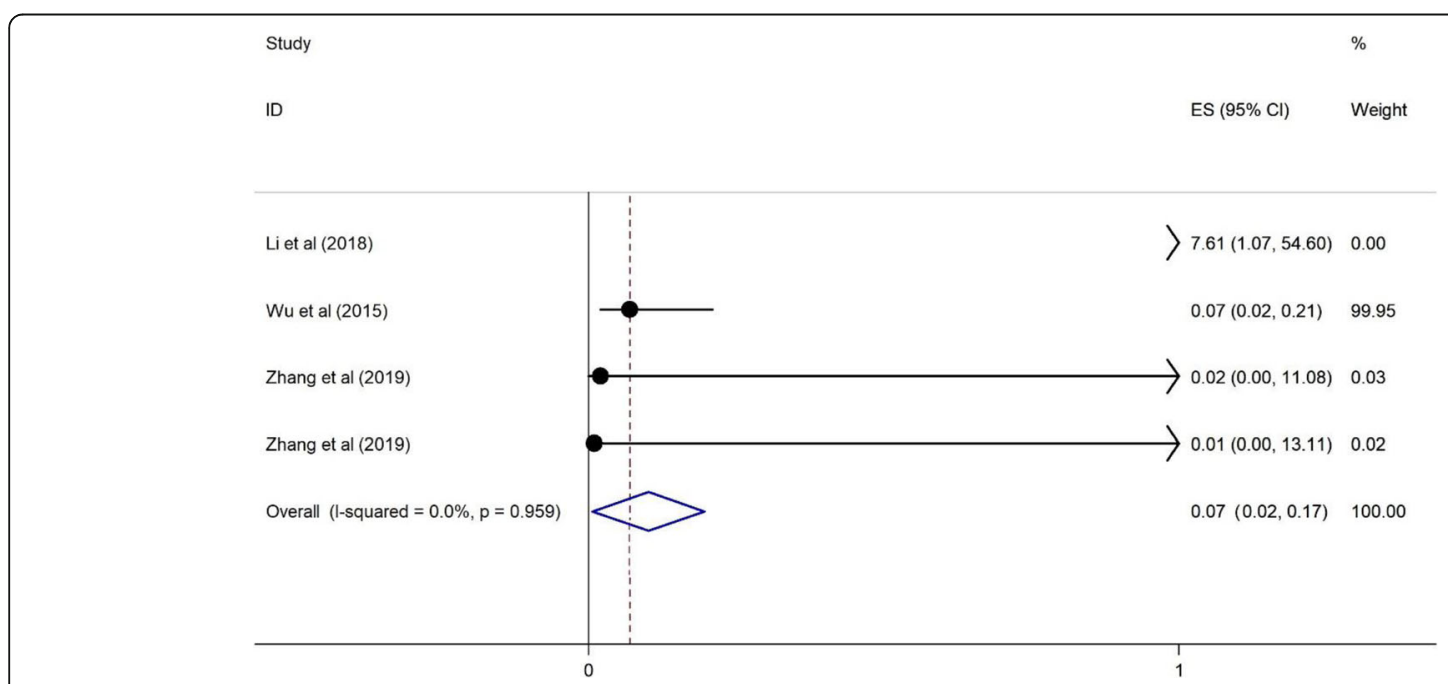

Fig. 7 Forest plots for the association between living with spouse and HIV related stigma among PLWH 


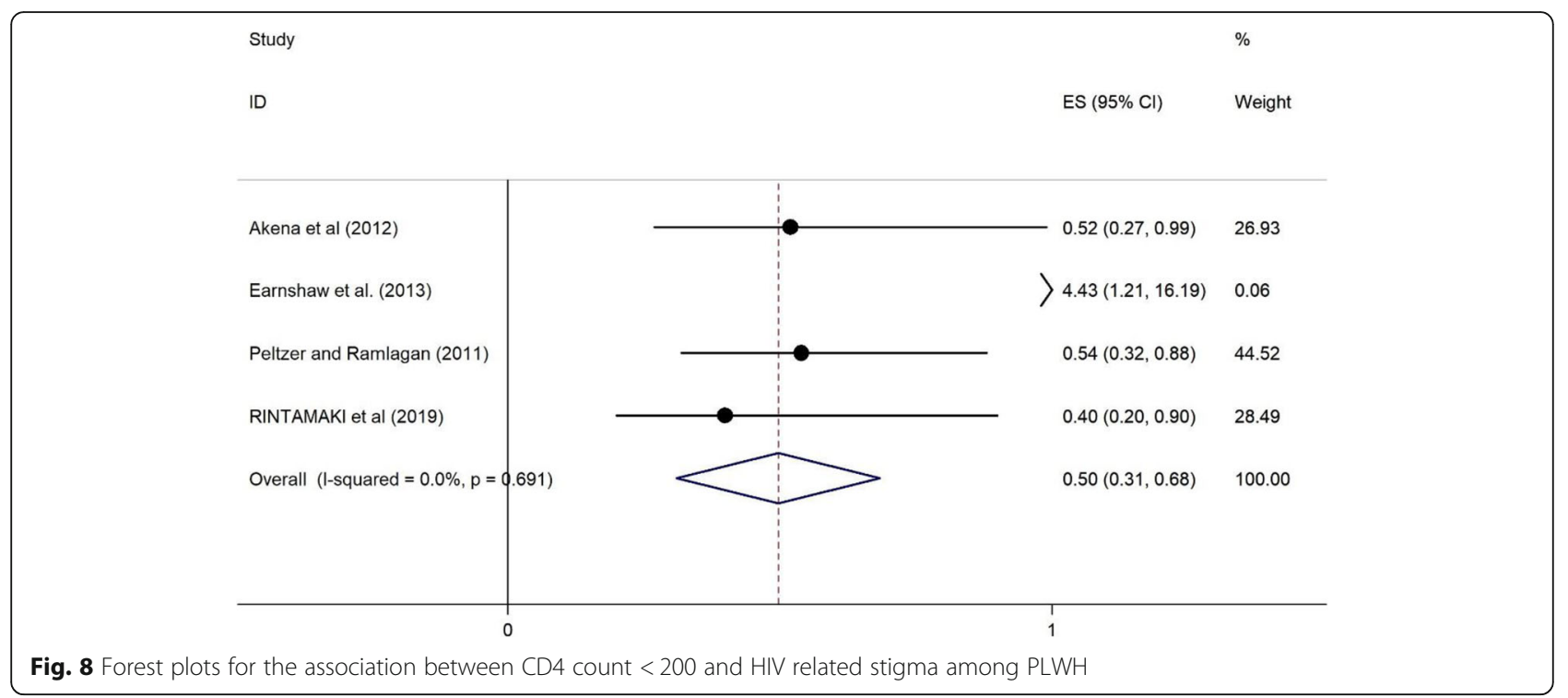

consistent with previous studies [27, 57] where living with a spouse might mediate the need to disclose their HIV status to others, therefore potentially protecting them from experiencing community based stigma.

In the present study we found that increasing age was significantly associated with lower rates of reporting HIV-related stigma. This finding is consistent with previous studies among PLWH $[27,58,59]$. In a longitudinal cohort study of almost 1000 PLWH in Ontario (Canada) it was found that while people's experiences of stigma may not decrease with age, the authors suggest that the internalization of stigma may indeed lessen over time [29]. It may also be explained by PLWH who are older having more social and family support therefore limiting their exposure to HIV-related stigma.

However, others socioeconomic variables (being female, having low levels of education and income) do not appear to have an association on the reporting of HRS. Positive socio-demographic characteristics were more strongly associated with HIV-related stigma than negative ones.

Our meta-analysis study data could be beneficial for the development of interventions designed to reduce exposure to HIV-related stigma and focused on improving the overall mental-health health status of PLWH. Appropriate measures are required to target several

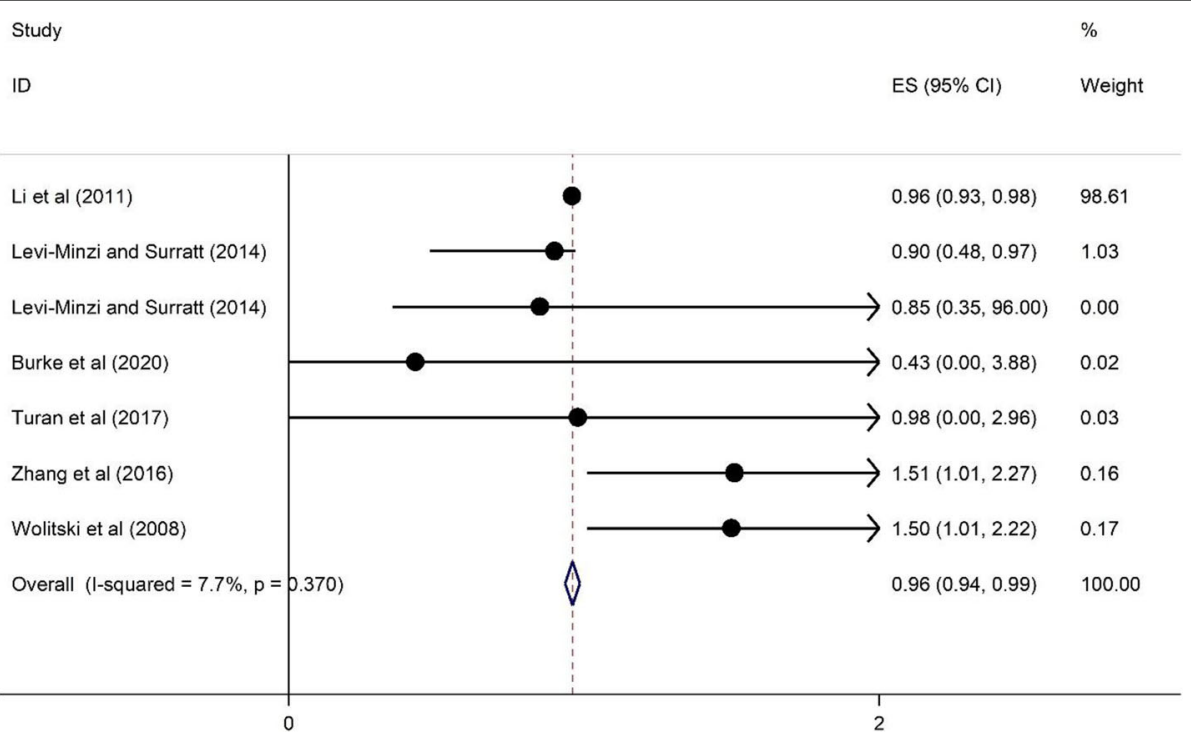

Fig. 9 Forest plots for the association between medication adherence and HIV related stigma among PLWH 


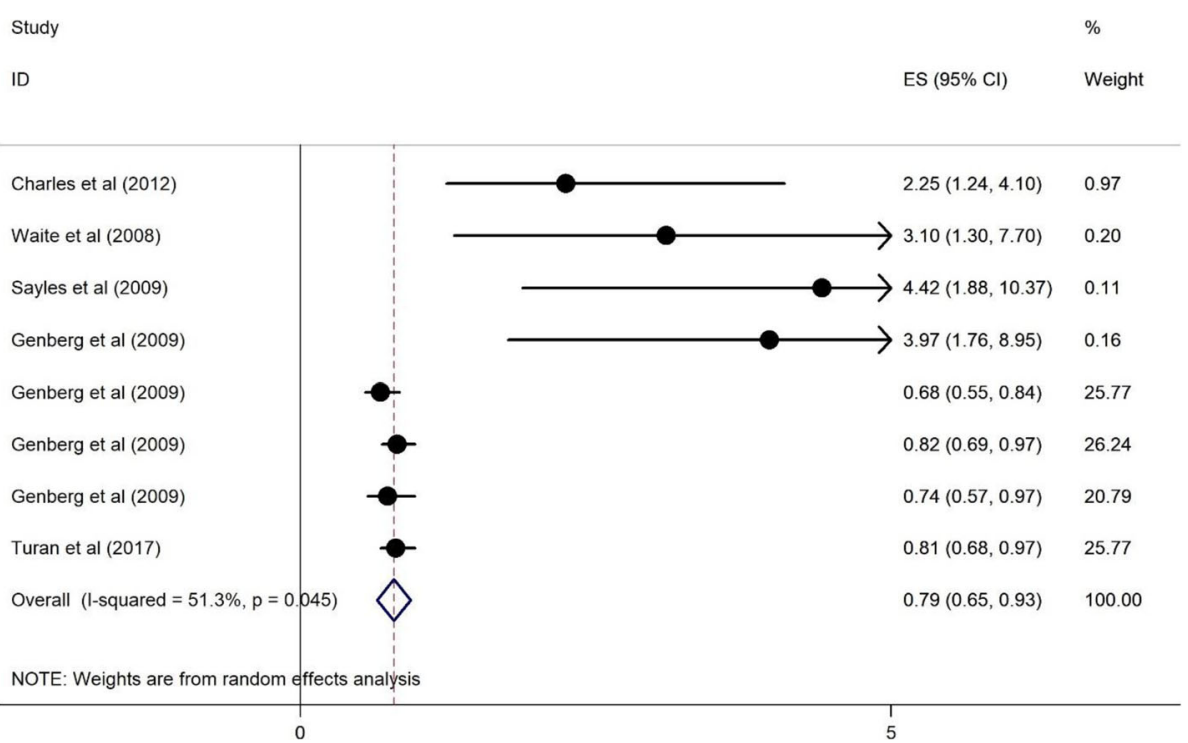

Fig. 10 Forest plots for the association between poor access to care and HIV related stigma among PLWH

populations (in terms of age, health, and socioeconomic status) for reducing various dimensions of HIV-related stigma (e.g. health care professionals, policymakers, PLWH and the communities in which they live) $[16,60$, 61]. HIV-related stigma could be prevented through the implementation of structural interventions [16], and by improving the economic status of PLWH, [60]. PLWH and health care professionals could utilize the current meta-analysis data to improve awareness of the most deleterious correlates of stigma and socioeconomic status. Stigma-reduction approaches that address the socioeconomic status needs of PLWH could be designed and implemented [62-64].

\section{Assumption 2: clinical determinants have an association} on HRS among PLWH

We found the protective correlation between HRS and CD4 counts. A previous study using multivariate data found that HIV-positive females revealed no relationship between HIV-related stigma and the physical health variables collected (i.e., viral load and CD4 counts) [65]. This highlights the importance of further research with an emphasis on controlling for potential confounding variables (e.g., sexual orientation, substance use).

We observed increased rates of HRS being reported by PLWH with lower CD4 counts. This may be explained by the effectiveness of ART medication adherence [66] it also suggests that individuals with CD4 count under 200
Study
ID
ES $(95 \% \mathrm{Cl}) \quad$ Weight

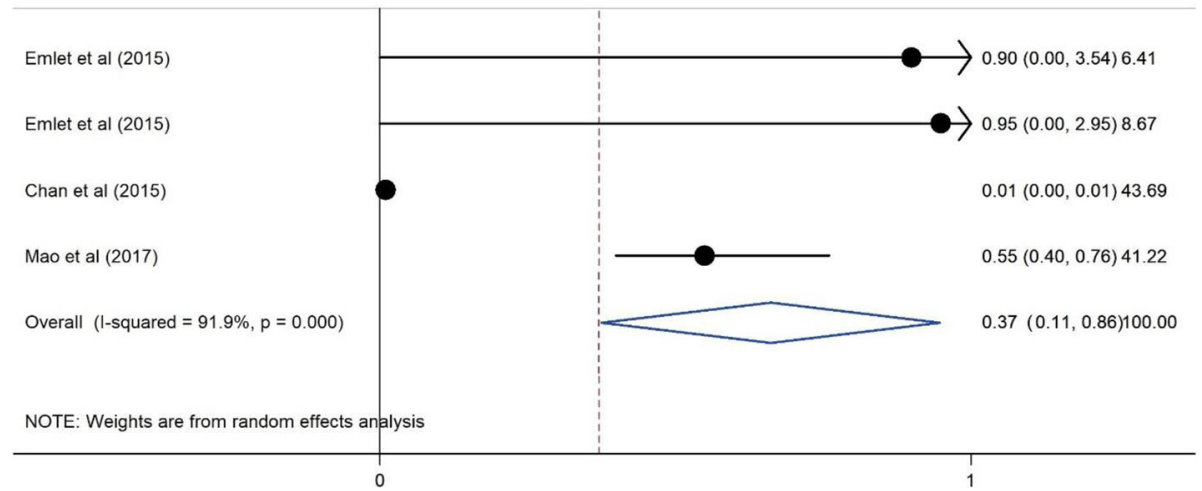

Fig. 11 Forest plots for the association between of time diagnosis and accessibility to cares and HIV related stigma among PLWH 
Table 4 Findings of publication bias using Eggers test

\begin{tabular}{|c|c|c|}
\hline \multirow[t]{5}{*}{ Demographical } & Age 30 & $C=3.98, P$ value $=0.179$ \\
\hline & Being female & Not calculated \\
\hline & Living with a spouse & Not calculated \\
\hline & more 100 dollar & $C=10.09, P$ value $=0.015$ \\
\hline & Non- literate and primary education & $C=1.69, P$ value $=0.173$ \\
\hline \multirow[t]{5}{*}{ Clinical } & Poor access to care & $C=1.86, P$ value $=0.360$ \\
\hline & Medical adhe & $C=1.28, P$ value $=0.195$ \\
\hline & CD4 & $C=1.82, P$ value $=0.576$ \\
\hline & Previous testing & $C=3.810, P$ value $=0.502$ \\
\hline & Time since HIV & Not calculated \\
\hline
\end{tabular}

are likely to require more attention from health care workers including palliative and supportive care and thereby exposing them to possible stigma. Previous studies have demonstrated an association between immunological status and health related quality of life where PLWH with higher CD4-cell count reported better physical health status [67-69]. PLWH who stared their ART at CD4 $<200$ cells/ $\mu$ l showed improved physical health status when compared to PLWH with 200-350 cells/ $\mu \mathrm{l}$ or $>350$ cells $/ \mu \mathrm{l}$, primarily because their physical health was worse when initiating treatment [70]. HIV treatment guidelines propose early initiation of ART (i.e. 350-500 celles/ $\mu \mathrm{l})$, as this slows the progression of HIV to AIDS and decreases mortality [71].

\section{Assumption 3: service use characteristics have an association on HRS among PLWH}

We also detected a mediating role for HIV-related stigma on service use (i.e., adherence to ART, and access to and use of other health and social services). In line with this finding, a similar systematic review and metaanalyses demonstrated that HIV-related stigma negatively association adherence to treatment especially when social support and adaptive coping strategies are undermined [72].

PLWH who face stigma or anticipate experiencing it may try to hide their HIV infection status which in turn may lead to late initiation or interrupted ART medication $[8,72]$. Some studies failed to identify any correlation between HIV-related stigma, and accessing and using health and social support $[73,74]$. However, other research has found HIV-related stigma was significantly related to decreased healthcare access [10] or delay in receiving such care [75] or perceived discrimination by healthcare staff $[76,77]$.

A large and increasing body of literature addresses the reverse correlation between stigma and pre-exposure prophylaxis [78], HIV care adherence and retention [10, 79, 80], HIV testing [81-83], adherence to HIV medications [72, 84-86] as well as the suppression of viral load
[81, 87, 88]. Previous work also suggests that HIV-based stigma negatively affects adherence to medication treatment in PLWH with most studies using a single measure of stigma to show adherence to treatment and stigma are correlated.

The present research data on the association between HIV-related stigma and reduced adherence to antiretroviral therapy is in line with prior research with specific study populations, such as injection drug users, females, and PLWH living outside the typical disease epicenters [13, 89]. Moreover, considering the above-mentioned points as well as the importance of adherence to HIV medication, stigma-centered conversations by clinicians with their patients must be considered before prescribing the patients with antiretroviral therapy. This may also involve more discrete pharmacotherapy regimens for PLWH highly sensitive to stigma as well as psychoeducational programs that increase social support and improve resilience. Further research is necessary to explore the association of community- and clinical-based stigma on the mental health needs of PLWH. Such measures could help eliminate the impact of stigma and reveal the influence of mediating factors on the HIV-induced stigma. Such data could be beneficial when developing HIV care and management plans that support PLWH.

Our findings are in line with those of previous research which highlights the impact of HRS on ART adherence, specifically in resource-limited settings [90, 91]. Our data could be used by policymakers to develop and implement HIV focused public health policies, including universal voluntary testing with immediate treatment in high prevalence HIV populations [92].

Similarly to results from Southern Wollo, Ethiopia [75] our study found stigma and HIV were related to late diagnosis of disease, i.e. participants reporting high levels of stigma were more likely to present late for HIV testing and diagnosis. This may be explained by internalized stigma, where those who remain un-tested do so because they do not want to face the stigma they perceive will be evident when or if they test positive to HIV. 
The present finding is also in line with data from HIV positive African Americans [93] where HIV-related stigma was found to decrease over time as those living with HIV receive information and come to more comprehensively understand their disease. In doing so they find mental health and social support to deal effectively with HIV stigma.

\section{Strength and limitation of study}

Our study had some limitations should be acknowledging, this is the first quantitative literature synthesis on the relationship between HIV-related stigma and the demographic, clinical and service use variables of PLWH. By restricting our study to peer-reviewed journals the data might be subject to publication bias. As we only included observational studies; we are unable to infer causal relationships between reported HIV-related stigma and other characteristics. The studies included applied a variety of instruments for assessing HIVrelated stigma and several studies developed and applied bespoke data collection tools or analyzed self-reported data. The limited number of studies $(N=31)$ also precluded subgroup analyses. Extending our understanding of the factors associated with HIV-related stigma could be beneficial for healthcare professionals working with PLWH and their support networks. Additionally, our study did not include research regarding the impact of stigma on pre-ART correlation with treatment [94, 95], or in people who refuse ART [160].

\section{Implications for future intervention design}

The relationship between the social and clinical determinants and HRS and adherence to ART is important when designing future interventions to enhance and improve adherence. For example, correlations between internalized stigma, and adherence need interventions that includes a cognitive-behavioral component (e.g., challenging internalized opinions related to affecting HIV, improving motivation to preserve optimal health,).

\section{Conclusions}

Our study supports the idea that HIV-related stigma has an association with a variety of health- related outcomes in people who are living with HIV. Our research demonstrated significant associations between HIV-related stigma and being aged $>30$ years, living with a spouse, CD4 count $<200$, adherence to antiretroviral therapy, and service availability. Our findings suggest that health care professionals and others working with PLWH can also assist in the planning of strategies which decrease the stigma related with taking medication. Our findings may be useful for PLWH and those working with them to improve knowledge of the most deleterious associations of stigma with physical and mental health. Our data suggest interventions that address stigma must focus on age, socio-economic status, gender, and culture and should be designed to identify experiences of social stigma, to reduce the most negative aspects of physical/ mental health for PLWH. This may ultimately help to create environments that facilitate social support groups for PLWH and the broader community. Considering the protective association stigma has on HIV prevention and treatment for PLWH, it is recommended that targeted evidence-based HIV stigma reduction interventions be developed. Focusing rigorously designed and evaluated interventions on a particular group, such as healthcare professionals and applying may also help to reduce HRS.

\section{Abbreviations \\ HRS: HIV-related stigma; PLWH: People living with HIV; PICO: Population, Intervention, Comparator, Outcomes; OR: Pooled odds ratio; \\ ART: Antiretroviral therapy; PRISMA: Protocols of Systematic Reviews and Meta-Analyses; WHO: World Health Organization}

\section{Acknowledgments}

Not applicable.

\section{Authors' contributions}

Study design: $B A$ and $A B$. Database searched, data extraction and data synthesis: BA, AHB, and YF. Initial manuscript draft: BA, AB, and LFM. Critical revision of the manuscript: $\mathrm{PH}, \mathrm{MJF}$ and $\mathrm{BA}$. All authors have read and approved the final version of the manuscript.

\section{Funding}

This research did not receive any specific grant from funding agencies in the public, commercial, or not -for -profit sectors. The funders had no role in study design, data collection and analysis, decision to publish, or preparation of the manuscript.

\section{Availability of data and materials}

The datasets used and/or analyzed during the current study are available from the corresponding author on reasonable request.

\section{Declarations}

Ethics approval and consent to participate Not Applicable.

\section{Consent for publication}

Not applicable.

\section{Competing interests}

The corresponding author BA is an Editorial Board Member for BMC Health Services Research. The authors declare that they have no competing interests.

\section{Author details}

${ }^{1}$ Research Center, Douglas Mental Health University Institute, 6875 LaSalle Blvd, Montreal, QC H4H 1R3, Canada. ²Department of Psychiatry, McGill University, 1033, Pine Avenue West, Montreal, QC H3A 1A1, Canada. ${ }^{3}$ Department of Public Health, School of Psychology and Public Health, La Trobe University, Melbourne, VIC, Australia. ${ }^{4}$ Management, Evaluation and Health Policies Department, School of Public Health, Université de Montréal, 7101 av. du Parc, Montreal, QC H3X1X9, Canada. ${ }^{5}$ Social Determinants of Health Research Center, Saveh University of Medical Sciences, Saveh, Iran. ${ }^{6}$ Department of nursing, faculty of nursing and midwifery, Tehran medical sciences, Islamic Azad University, Tehran, Iran. ${ }^{7}$ Student Research Committee, School of Allied Medical Sciences, Shahid Beheshti University of Medical Sciences, Tehran, Iran. ${ }^{8}$ Social Determinants in Health Promotion Research Center, Hormozgan Health Institute, Hormozgan University of Medical Sciences, Bandar Abbas, Iran. 
Received: 16 December 2020 Accepted: 2 September 2021 Published online: 22 September 2021

\section{References}

1. Mahajan AP, Sayles JN, Patel VA, Remien RH, Ortiz D, Szekeres G, et al. Stigma in the HIV/AIDS epidemic: a review of the literature and recommendations for the way forward. AIDS (London, England). 2008; 22(Suppl 2):S67.

2. Parker R, Aggleton P. HIV and AIDS-related stigma and discrimination: a conceptual framework and implications for action. Soc Sci Med (1982). 2003;57(1):13-24.

3. Van Brakel WH. Measuring health-related stigma--a literature review. Psychol Health Med. 2006;11(3):307-34. https://doi.org/10.1080/13548500600595160.

4. Campbell C, Deacon $\mathrm{H}$. Unravelling the contexts of stigma: from internalisation to resistance to change. J Community Appl Soc Psychol. 2006;16(6):411-7. https://doi.org/10.1002/casp.901.

5. Bayat A-H, Mohammadi R, Moradi-Joo M, Bayani A, Ahounbar E, Higgs P, et al. HIV and drug related stigma and risk-taking behaviors among people who inject drugs: a systematic review and meta-analysis. J Addict Dis. 2020; 38(1):71-83. https://doi.org/10.1080/10550887.2020.1718264

6. Rueda S, Mitra S, Chen S, Gogolishvili D, Globerman J, Chambers L, et al. Examining the associations between HIV-related stigma and health outcomes in people living with HIV/AIDS: a series of meta-analyses. BMJ Open. 2016;6(7):e011453. https://doi.org/10.1136/bmjopen-2016-011453.

7. Gesesew HA, Tesfay Gebremedhin A, Demissie TD, Kerie MW, Sudhakar M, Mwanri L. Significant association between perceived HIV related stigma and late presentation for HIV/AIDS care in low and middle-income countries: a systematic review and meta-analysis. PLoS One. 2017;12(3):e0173928. https://doi.org/10.1371/journal.pone.0173928.

8. Rintamaki LS, Davis TC, Skripkauskas S, Bennett CL, Wolf MS. Social stigma concerns and HIV medication adherence. AIDS Patient Care STDs. 2006; 20(5):359-68. https://doi.org/10.1089/apc.2006.20.359.

9. Charles B, Jeyaseelan L, Pandian AK, Sam AE, Thenmozhi M, Jayaseelan V. Association between stigma, depression and quality of life of people living with HIV/AIDS (PLHA) in South India - a community based cross sectional study. BMC Public Health. 2012;12(1):463. https://doi.org/10.1186/1471-24 58-12-463.

10. Steward WT, Bharat S, Ramakrishna J, Heylen E, Ekstrand ML. Stigma is associated with delays in seeking care among HIV-infected people in India. J Int Assoc Provid AIDS Care. 2013;12(2):103-9. https://doi.org/10.1177/154 5109711432315.

11. Gardner EM, McLees MP, Steiner JF, Del Rio C, Burman WJ. The spectrum of engagement in HIV care and its relevance to test-and-treat strategies for prevention of HIV infection. Clin Infect Dis. 2011;52(6):793-800. https://doi. org/10.1093/cid/ciq243.

12. Boer $H$, Emons PA. Accurate and inaccurate HIV transmission beliefs, stigmatizing and HIV protection motivation in northern Thailand. AIDS Care. 2004;16(2):167-76. https://doi.org/10.1080/09540120410001641011.

13. Carr RL, Gramling LF. Stigma: a health barrier for women with HIV/AIDS. J Assoc Nurs AIDS Care : JANAC. 2004;15(5):30-9. https://doi.org/10.1177/1 055329003261981.

14. Turan JM, Miller S, Bukusi EA, Sande J, Cohen CR. HIV/AIDS and maternity care in Kenya: how fears of stigma and discrimination affect uptake and provision of labor and delivery services. AIDS Care. 2008;20(8):938-45. https://doi.org/10.1080/09540120701767224

15. Sayles JN, Wong MD, Kinsler JJ, Martins D, Cunningham WE. The association of stigma with self-reported access to medical care and antiretroviral therapy adherence in persons living with HIV/AIDS. J Gen Intern Med. 2009; 24(10):1101-8. https://doi.org/10.1007/s11606-009-1068-8

16. Klein SJ, Karchner WD, O'Connell DA. Interventions to prevent HIV-related stigma and discrimination: findings and recommendations for public health practice. J Publ Health Manage Pract. 2002;8(6):44-53. https://doi.org/10.1 097/00124784-200211000-00007.

17. Shamseer L, Moher D, Clarke M, Ghersi D, Liberati A, Petticrew M, et al. Preferred reporting items for systematic review and meta-analysis protocols (PRISMA-P) 2015: elaboration and explanation. BMJ. 2015;2(350):g7647. https://doi.org/10.1136/bmj.g7647.

18. Stroup DF, Berlin JA, Morton SC, Olkin I, Williamson GD, Rennie D, et al, Meta-analysis of observational studies in epidemiology: a proposal for reporting. JAMA. 2000;283(15):2008-12. https://doi.org/10.1001/jama.283.15.2 008.
19. Ghiasvand H, Waye KM, Noroozi M, Harouni GG, Armoon B, Bayani A. Clinical determinants associated with quality of life for people who live with HIV/AIDS: a meta-analysis. BMC Health Serv Res. 2019;19(1):768. https://doi. org/10.1186/s12913-019-4659-Z.

20. Ghiasvand H, Bayani A, Noroozi A, Marshall BD, Koohestani HR, Hemmat M, et al. Comparing injecting and sexual risk behaviors of long-term injectors with new injectors: a meta-analysis. J Addict Dis. 2018;37(3-4):233-44. https://doi.org/10.1080/10550887.2019.1666622.

21. Berger BE, Ferrans CE, Lashley FR. Measuring stigma in people with HIV: psychometric assessment of the HIV stigma scale. Res Nurs Health. 2001; 24(6):518-29. https://doi.org/10.1002/nur.10011.

22. Sowell RL, Lowenstein A, Moneyham L, Demi A, Mizuno Y, Seals BF. Resources, stigma, and patterns of disclosure in rural women with HIV infection. Publ Health Nurs (Boston, Mass). 1997;14(5):302-12.

23. Kalichman SC, Simbayi LC, Cloete A, Mthembu PP, Mkhonta RN, Ginindza T. Measuring AIDS stigmas in people living with HIV/AIDS: the internalized AIDS-related stigma scale. AIDS Care. 2009;21(1):87-93. https://doi.org/10.1 080/09540120802032627.

24. Stang A. Critical evaluation of the Newcastle-Ottawa scale for the assessment of the quality of nonrandomized studies in meta-analyses. Eur J Epidemiol. 2010;25(9):603-5. https://doi.org/10.1007/s10654-010-9491-z.

25. Higgins JP, Green S. Cochrane handbook for systematic reviews of interventions, vol. 4: Wiley; 2011.

26. Waite KR, Paasche-Orlow M, Rintamaki LS, Davis TC, Wolf MS. Literacy, social stigma, and HIV medication adherence. J Gen Intern Med. 2008;23(9):136772. https://doi.org/10.1007/s11606-008-0662-5.

27. Li Z, Morano JP, Khoshnood K, Hsieh E, Sheng Y. HIV-related stigma among people living with HIV/AIDS in rural Central China. 2018;18(1):453. https:// doi.org/10.1186/s12913-018-3245-0.

28. Egbe TO, Nge CA, Ngouekam H, Asonganyi E, Nsagha DS. Stigmatization among people living with HIV/AIDS at the Kumba Health District, Cameroon. J Int Assoc Provid AIDS Care. 2020;19:2325958219899305. https:// doi.org/10.1177/2325958219899305.

29. Emlet CA, Brennan DJ, Brennenstuhl S, Rueda S, Hart TA, Rourke SB. The impact of HIV-related stigma on older and younger adults living with HIV disease: does age matter? AIDS Care. 2015;27(4):520-8. https://doi.org/10.1 080/09540121.2014.978734.

30. Akena D, Musisi S, Joska J, Stein DJ. The association between aids related stigma and major depressive disorder among HIV-positive individuals in Uganda. PLoS One. 2012;7(11):e48671. https://doi.org/10.1371/journal.pone. 0048671.

31. Letshwenyo-Maruatona SB, Madisa M, Boitshwarelo T, George-Kefilwe B, Kingori C, Ice G, et al. Association between HIV/AIDS knowledge and stigma towards people living with HIV/AIDS in Botswana. Afr J AIDS Res: AJAR. 2019;18(1):58-64. https://doi.org/10.2989/16085906.2018.1552879.

32. Chan BT, Weiser SD, Boum Y, Siedner MJ, Mocello AR, Haberer JE, et al. Persistent HIV-related stigma in rural Uganda during a period of increasing HIV incidence despite treatment expansion. AIDS (London, England). 2015; 29(1):83-90.

33. Wu F, He X, Guida J, Xu Y, Liu H. Network stigma towards people living with HIV/AIDS and their caregivers: an egocentric network study. Glob Public Health. 2015;10(9):1032-45. https://doi.org/10.1080/17441692.2014.1 003572.

34. Rael CT, Hampanda K. Understanding internalized HIV/AIDS-related stigmas in the Dominican Republic: a short report. AIDS Care. 2016;28(3):319-24. https://doi.org/10.1080/09540121.2015.1095277.

35. Zhang Q, Yang H, Fan J, Duan L, Chen D, Feng X, et al. Older people living with human immunodeficiency virus/acquired immune deficiency syndrome in Chinese rural areas: perceived stigma and associated factors. Trans R Soc Trop Med Hyg. 2019;113(8):477-82. https://doi.org/10.1093/ trstmh/trz033.

36. Peltzer K, Ramlagan S. Perceived stigma among patients receiving antiretroviral therapy: a prospective study in KwaZulu-Natal, South Africa. AIDS Care. 2011;23(1):60-8. https://doi.org/10.1080/09540121.2010.498864.

37. Zhang C, Li X, Liu Y, Qiao S, Zhou Y, Shen Z, et al. Substance use and psychosocial status among people living with HIV/AIDS who encountered HIV stigma in China: stratified analyses by socio-economic status. PLoS One. 2016;11(11):e0165624. https://doi.org/10.1371/journal.pone.0165624.

38. Srithanaviboonchai K, Chariyalertsak S, Nontarak J, Assanangkornchai S, Kessomboon $\mathrm{P}$, Putwatana $\mathrm{P}$, et al. Stigmatizing attitudes toward people living with HIV among general adult Thai population: results from the 5th 
Thai National Health Examination Survey (NHES). PLoS One. 2017;12(11): e0187231. https://doi.org/10.1371/journal.pone.0187231.

39. Li X, Yuan L, Li X, Shi J, Jiang L, Zhang C, et al. Factors associated with stigma attitude towards people living with HIV among general individuals in Heilongjiang, Northeast China. BMC Infect Dis. 2017;17(1):154. https://doi. org/10.1186/s12879-017-2216-0.

40. Stangl AL, Lilleston P, Mathema H, Pliakas T, Krishnaratne S, Sievwright $K$, et al. Development of parallel measures to assess HIV stigma and discrimination among people living with HIV, community members and health workers in the HPTN 071 (PopART) trial in Zambia and South Africa. J Int AIDS Soc. 2019;22(12):e25421. https://doi.org/10.1002/jia2.25421.

41. Stevelink SA, van Brakel WH, Augustine V. Stigma and social participation in southern India: differences and commonalities among persons affected by leprosy and persons living with HIV/AIDS. Psychol Health Med. 2011;16(6): 695-707. https://doi.org/10.1080/13548506.2011.555945.

42. Zhang C, Li X, Liu Y, Qiao S, Zhang L, Zhou Y, et al. Emotional, physical and financial burdens of stigma against people living with HIV/AIDS in China. AIDS Care. 2016;28 Suppl 1(sup1):124-31.

43. Rivera AV, DeCuir J, Crawford ND, Amesty S, Harripersaud K, Lewis CF. Factors associated with HIV stigma and the impact of a nonrandomized multi-component video aimed at reducing HIV stigma among a high-risk population in New York City. AIDS Care. 2015;27(6):772-6. https://doi.org/1 0.1080/09540121.2014.998611.

44. Li X, Huang L, Wang H, Fennie KP, He G, Williams AB. Stigma mediates the relationship between self-efficacy, medication adherence, and quality of life among people living with HIV/AIDS in China. AIDS Patient Care STDs. 2011; 25(11):665-71. https://doi.org/10.1089/apc.2011.0174.

45. Genberg BL, Hlavka Z, Konda KA, Maman S, Chariyalertsak S, Chingono A, et al. A comparison of HIV/AIDS-related stigma in four countries: negative attitudes and perceived acts of discrimination towards people living with HIV/AIDS. Soc Sci Med (1982). 2009;68(12):2279-87.

46. Earnshaw VA, Smith LR, Chaudoir SR, Amico KR, Copenhaver MM. HIV stigma mechanisms and well-being among PLWH: a test of the HIV stigma framework. AIDS Behav. 2013;17(5):1785-95. https://doi.org/10.1007/s10461013-0437-9.

47. Burke SE, Calabrese SK, Dovidio JF, Levina OS, Uusküla A, Niccolai LM, et al. A tale of two cities: stigma and health outcomes among people with HIV who inject drugs in St. Petersburg, Russia and Kohtla-Järve, Estonia. Soc Sci Med (1982). 2015;130:154-61.

48. Turan B, Rogers AJ, Rice WS, Atkins GC, Cohen MH, Wilson TE, et al. Association between perceived discrimination in healthcare settings and HIV medication adherence: mediating psychosocial mechanisms. AIDS Behav. 2017;21(12):3431-9. https://doi.org/10.1007/s10461-017-1957-5.

49. Mao Y, Li X, Qiao S, Zhao Q, Zhou Y, Shen Z. Social support, stigma, and HIV disclosure among parents living with HIV in Guangxi, China. AIDS Care. 2018;30(2):168-72. https://doi.org/10.1080/09540121.2017.1387639.

50. Zhang C, Li X, Liu Y, Qiao S, Zhang L, Zhou Y, et al. Stigma against people living with HIV/AIDS in China: does the route of infection matter? PLoS One. 2016;11(3):e0151078. https://doi.org/10.1371/journal.pone.0151078.

51. Rintamaki L, Kosenko K, Hogan T, Scott AM, Dobmeier C, Tingue E, et al. The role of stigma management in HIV treatment adherence. Int J Environ Res Public Health. 2019;16(24):5003. https://doi.org/10.3390/ijerph16245003.

52. Liu C, Zhang Y, Pan SW, Cao B, Ong JJ, Fu H, et al. Anticipated HIV stigma among HIV negative men who have sex with men in China: a crosssectional study. BMC Infect Dis. 2020;20(1):44. https://doi.org/10.1186/s12 879-020-4778-5.

53. Wolitski RJ, Pals SL, Kidder DP, Courtenay-Quirk C, Holtgrave DR. The effects of HIV stigma on health, disclosure of HIV status, and risk behavior of homeless and unstably housed persons living with HIV. AIDS Behav. 2009; 13(6):1222-32. https://doi.org/10.1007/s10461-008-9455-4.

54. Levi-Minzi MA, Surratt HL. HIV stigma among substance abusing people living with HIV/AIDS: implications for HIV treatment. AIDS Patient Care STDs. 2014;28(8):442-51. https://doi.org/10.1089/apc.2014.0076.

55. Begg CB, Mazumdar M. Operating characteristics of a rank correlation test for publication bias. Biometrics. 1994;50(4):1088-101. https://doi.org/10.23 07/2533446.

56. Egger M, Smith GD, Schneider M, Minder C. Bias in meta-analysis detected by a simple, graphical test. BMJ. 1997;315(7109):629-34. https://doi.org/1 0.1136/bmj.315.7109.629.
57. Zhang YJ, Fan YG, Dai SY, Li BZ, Xu WD, Hu LF, et al. HIV/AIDS stigma among older PLWHA in south rural China. Int J Nurs Pract. 2015;21(3):221-8. https://doi.org/10.1111/ijn.12254.

58. Loutfy MR, Logie CH, Zhang Y, Blitz SL, Margolese SL, Tharao WE, et al. Gender and ethnicity differences in HIV-related stigma experienced by people living with HIV in Ontario, Canada. PLoS One. 2012;7(12):e48168. https://doi.org/10.1371/journal.pone.0048168.

59. Ghiasvand H, Higgs P, Noroozi M, Ghaedamini Harouni G, Hemmat M, Ahounbar $E$, et al. Social and demographical determinants of quality of life in people who live with HIV/AIDS infection: evidence from a meta-analysis. Biodemography Soc Biol. 2020;65(1):57-72. https://doi.org/10.1080/194 85565.2019.1587287.

60. Prost A, Elford J, Imrie J, Petticrew M, Hart GJ. Social, Behavioural, and intervention research among people of sub-Saharan African origin living with HIV in the UK and Europe: literature review and recommendations for intervention. AIDS Behav. 2008;12(2):170-94. https://doi.org/10.1007/s10461007-9237-4.

61. Waterman H, Griffiths J, Gellard L, O'Keefe C, Olang G, Ayuyo J, et al. Power brokering, empowering, and educating: the role of home-based care professionals in the reduction of HIV-related stigma in Kenya. Qual Health Res. 2007;17(8):1028-39. https://doi.org/10.1177/1049732307307524.

62. Acevedo V. Cultural competence in a group intervention designed for Latino patients living with HIV/AIDS. Health Soc Work. 2008;33(2):111-20. https://doi.org/10.1093/hsw/33.2.111.

63. Foster PH. Use of stigma, fear, and denial in development of a framework for prevention of HIV/AIDS in rural African American communities. Family Commun Health. 2007;30(4):318-27. https://doi.org/10.1097/01.FCH.00002 90544.48576.01.

64. Kang E, Mellins CA, Ng WYK, Robinson L-G, Abrams EJ. Standing between two worlds in Harlem: a developmental psychopathology perspective of perinatally acquired human immunodeficiency virus and adolescence. J Appl Dev Psychol. 2008;29(3):227-37. https://doi.org/10.1016/j.appdev.2008. 02.001.

65. Wagner AC, Hart TA, Mohammed S, Ivanova E, Wong J, Loutfy MR. Correlates of HIV stigma in HIV-positive women. Arch Women's Mental Health. 2010;13(3):207-14. https://doi.org/10.1007/s00737-010-0158-2.

66. Achappa B, Madi D, Bhaskaran U, Ramapuram JT, Rao S, Mahalingam S. Adherence to antiretroviral therapy among people living with HIV. N Am J Med Sci. 2013;5(3):220-3. https://doi.org/10.4103/1947-2714.109196.

67. Armon $\mathrm{C}$, Lichtenstein $\mathrm{K}$. The associations among coping, nadir CD4+ T-cell count, and non-HIV-related variables with health-related quality of life among an ambulatory HIV-positive patient population. Qual Life Res Int J Qual Life Asp Treat Care Rehab. 2012;21(6):993-1003. https://doi.org/10.1 007/s11136-011-0017-2.

68. Murri R, Fantoni M, Del Borgo C, Visona R, Barracco A, Zambelli A, et al. Determinants of health-related quality of life in HIV-infected patients. AIDS Care. 2003;15(4):581-90. https://doi.org/10.1080/0954012031000134818.

69. Call SA, Klapow JC, Stewart KE, Westfall AO, Mallinger AP, DeMasi RA, et al. Health-related quality of life and virologic outcomes in an HIV clinic. Qual Life Res Int J Qual Life Asp Treat Care Rehab. 2000;9(9):977-85. https://doi. org/10.1023/A:1016668802328.

70. Nieuwkerk PT, Hillebrand-Haverkort ME, Vriesendorp R, Frissen PH, de Wolf F, Sprangers MA. Quality of life after starting highly active antiretroviral therapy for chronic HIV-1 infection at different CD4 cell counts. J Acquired Immune Deficiency Syndr (1999). 2007:45(5):600-1.

71. Degroote S, Vogelaers D, Vandijck DM. What determines health-related quality of life among people living with HIV: an updated review of the literature. Arch Publ Health = Archives belges de sante publique. 2014;72(1): 40.

72. Katz IT, Ryu AE, Onuegbu AG, Psaros C, Weiser SD, Bangsberg DR, et al. Impact of HIV-related stigma on treatment adherence: systematic review and meta-synthesis. J Int AIDS Soc. 2013;16(3 Suppl 2):18640. https://doi. org/10.7448/IAS.16.3.18640.

73. Naar-King S, Bradford J, Coleman S, Green-Jones M, Cabral H, Tobias C. Retention in care of persons newly diagnosed with HIV: outcomes of the outreach initiative. AIDS Patient Care STDs. 2007;21(Suppl 1):S40-8. https:// doi.org/10.1089/apc.2007.9988.

74. Dietz E, Clum GA, Chung S-E, Leonard L, Murphy DA, Perez LV, et al. Adherence to scheduled appointments among HIV-infected female youth in five U.S. cities. J Adolesc Health. 2010;46(3):278-83. https://doi.org/10.101 6/j.jadohealth.2009.06.013. 
75. Abaynew Y, Deribew A, Deribe K. Factors associated with late presentation to HIV/AIDS care in south Wollo ZoneEthiopia: a case-control study. AIDS Res Ther. 2011;8(1):8-8. https://doi.org/10.1186/1742-6405-8-8.

76. Kinsler JJ, Wong MD, Sayles JN, Davis C, Cunningham WE. The effect of perceived stigma from a health care provider on access to care among a low-income HIV-positive population. AIDS Patient Care STDs. 2007;21(8): 584-92. https://doi.org/10.1089/apc.2006.0202.

77. Nyamathi A, Ekstrand M, Zolt-Gilburne J, Ganguly K, Sinha S, Ramakrishnan $P$, et al. Correlates of stigma among rural Indian women living with HIV/ AIDS. AIDS Behav. 2013;17(1):329-39. https://doi.org/10.1007/s10461-0110041-9.

78. Card KG, Hawkins BW, Mortazavi L, Gregory A, Ng KH, Lachowsky NJ. Stigma, the media, and pre-exposure prophylaxis for HIV prevention: observations for enhancing knowledge translation and resisting stigma in the Canadian context. AIDS Behav. 2019;23(7):1877-87. https://doi.org/10.1 007/s10461-018-2332-x.

79. Gyamfi E, Okyere P, Enoch A, Appiah-Brempong E. Prevalence of, and barriers to the disclosure of HIV status to infected children and adolescents in a district of Ghana. BMC Int Health Hum Rights. 2017;17(1):8. https://doi. org/10.1186/s12914-017-0114-6.

80. Valverde E, Rodriguez A, White B, Guo Y, Waldrop-Valverde D. "Understanding the Association of Internalized HIV Stigma with Retention in HIV Care." J HIV and AIDS. 2018;4(3). https://doi.org/10.16966/2380-5536.159.

81. Ekstrand ML, Bharat S, Srinivasan K. HIV stigma is a barrier to achieving $90-$ 90-90 in India. Lancet HIV. 2018;5(10):e543-5. https://doi.org/10.1016/S23 52-3018(18)30246-7.

82. Young SD, Bendavid E. The relationship between HIV testing, stigma, and health service usage. AIDS Care. 2010;22(3):373-80. https://doi.org/10.1080/ 09540120903193666

83. Musheke M, Ntalasha H, Gari S, McKenzie O, Bond V, Martin-Hilber A, et al. A systematic review of qualitative findings on factors enabling and deterring uptake of HIV testing in sub-Saharan Africa. BMC Public Health. 2013;13(1): 220. https://doi.org/10.1186/1471-2458-13-220

84. Sweeney SM, Vanable PA. The association of HIV-related stigma to HIV medication adherence: a systematic review and synthesis of the literature. AIDS Behav. 2016;20(1):29-50. https://doi.org/10.1007/s10461-015-1164-1.

85. Nurfalah F, Yona S, Waluyo A. The relationship between HIV stigma and adherence to antiretroviral (ARV) drug therapy among women with HIV in Lampung, Indonesia. Enfermeria Clin. 2019;29(Suppl 2):234-7. https://doi. org/10.1016/j.enfcli.2019.04.138.

86. Dlamini PS, Wantland D, Makoae LN, Chirwa M, Kohi TW, Greeff M, et al. HIV stigma and missed medications in HIV-positive people in five African countries. AIDS Patient Care STDs. 2009;23(5):377-87. https://doi.org/10.1 089/apc.2008.0164.

87. Edwards RJ, Cyrus E, Bhatt C, Lyons N, Lavia LO, Boyce G. Viral suppression among persons living with HIV in Trinidad \& Tobago: implications for targeted prevention programmes. Glob Public Health. 2019;14(11):1569-77. https://doi.org/10.1080/17441692.2019.1633379.

88. Kemp CG, Lipira L, Huh D, Nevin PE, Turan JM, Simoni JM, et al. HIV stigma and viral load among African-American women receiving treatment for HIV. Aids. 2019;33(9):1511-9. https://doi.org/10.1097/QAD.0000000000002212.

89. Simoni JM, Kurth AE, Pearson CR, Pantalone DW, Merrill JO, Frick PA. Selfreport measures of antiretroviral therapy adherence: a review with recommendations for HIV research and clinical management. AIDS Behav. 2006;10(3):227-45. https://doi.org/10.1007/s10461-006-9078-6.

90. Tsai AC, Bangsberg DR. The importance of social ties in sustaining medication adherence in resource-limited settings. J Gen Intern Med. 2011; 26(12):1391-3. https://doi.org/10.1007/s11606-011-1841-3.

91. Bangsberg DR, Deeks SG. Spending more to save more: interventions to promote adherence. Ann Intern Med. 2010;152(1):54-6 w-13.

92. Granich RM, Gilks CF, Dye C, De Cock KM, Williams BG. Universal voluntary HIV testing with immediate antiretroviral therapy as a strategy for elimination of HIV transmission: a mathematical model. Lancet (London, England). 2009;373(9657):48-57.

93. Galvan FH, Davis EM, Banks D, Bing EG. HIV stigma and social support among African Americans. AIDS Patient Care STDs. 2008;22(5):423-36. https://doi.org/10.1089/apc.2007.0169.

94. Bassett IV, Wang B, Chetty S, Mazibuko M, Bearnot B, Giddy J, et al. Loss to care and death before antiretroviral therapy in Durban, South Africa. J Acquired Immune Deficiency Syndr (1999). 2009:51(2):135-9.
95. Losina E, Bassett IV, Giddy J, Chetty S, Regan S, Walensky RP, et al. The "ART" of linkage: pre-treatment loss to care after HIV diagnosis at two PEPFAR sites in Durban, South Africa. PLoS One. 2010;5(3):e9538. https://doi.org/1 0.1371/journal.pone.0009538.

\section{Publisher's Note}

Springer Nature remains neutral with regard to jurisdictional claims in published maps and institutional affiliations.
Ready to submit your research? Choose BMC and benefit from:

- fast, convenient online submission

- thorough peer review by experienced researchers in your field

- rapid publication on acceptance

- support for research data, including large and complex data types

- gold Open Access which fosters wider collaboration and increased citations

- maximum visibility for your research: over $100 \mathrm{M}$ website views per year

At BMC, research is always in progress.

Learn more biomedcentral.com/submissions 